DIW BERLIN

Discussion Papers

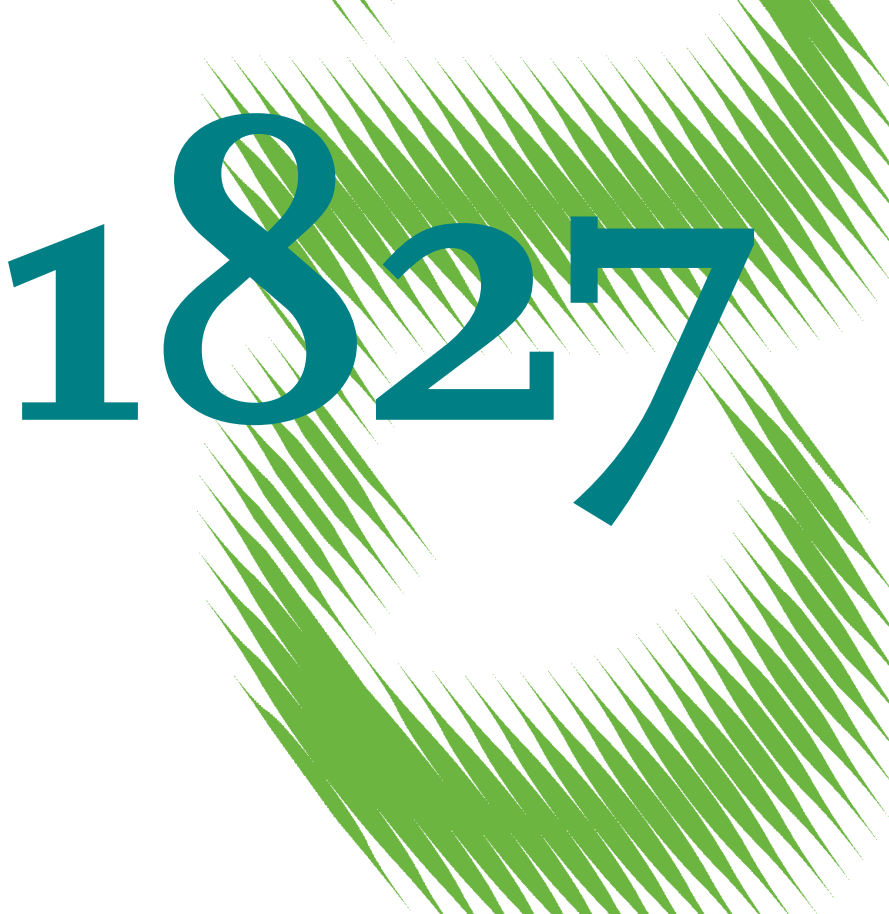

The Role of Labor Demand in the Labor Market Effects of a Pension Reform 
Opinions expressed in this paper are those of the author(s) and do not necessarily reflect views of the institute.

IMPRESSUM

(C) DIW Berlin, 2019

DIW Berlin

German Institute for Economic Research

Mohrenstr. 58

10117 Berlin

Tel. +49 (30) $89789-0$

Fax +49 (30) $89789-200$

http://www.diw.de

ISSN electronic edition 1619-4535

Papers can be downloaded free of charge from the DIW Berlin website:

http://www.diw.de/discussionpapers

Discussion Papers of DIW Berlin are indexed in RePEc and SSRN:

http://ideas.repec.org/s/diw/diwwpp.html

http://www.ssrn.com/link/DIW-Berlin-German-Inst-Econ-Res.html 


\title{
The Role of Labor Demand in the Labor Market Effects of a Pension Reform
}

\author{
Johannes Geyer \\ (DIW Berlin) \\ Peter Haan \\ (DIW Berlin, Free University of Berlin) \\ Svenja Lorenz \\ (University of Würzburg) \\ Mona Pfister \\ (University of Würzburg) \\ Thomas Zwick \\ (University of Würzburg, ZEW Mannheim) ${ }^{1}$
}

\begin{abstract}
This paper shows that labor demand plays an important role in the labor market reactions of older women affected by pension deductions for early retirement. Based on a large representative sample of the German workforce (SIAB), we calculate the consequences of individual financial incentive changes caused by a pension reform in Germany on employment, unemployment, and partial retirement. The reform reduces financial incentives for early retirement. In line with labor demand theory, we show that employers with a high share of older worker inflow compared with the share of younger worker inflow, employers in sectors with a high share of collective bargaining agreements, and employers in sectors with few investments in research and development are more responsive to their employees' demand to stay longer in the labor market. These employer groups mainly offer their older employees the option of staying longer in partial retirement instead of forcing them into unemployment before retirement.
\end{abstract}

Keywords: pension reform, labor demand effects, early retirement, employer heterogeneity

JEL classification: J14; J18; J22; J26; H31

\footnotetext{
${ }^{1}$ We would like to thank Dana Müller and Philipp vom Berge for their help with the data. We thank Mario Bossler, Wolfgang Frimmel, Elena Cottini, Annalisa Cristini, Claudio Lucifora, and Federica Origo for helpful comments and discussions. We are grateful to many conference and seminar participants for insightful comments and suggestions. Work on this paper was partially financed by the German Research Foundation (DFG grant numbers ZW172/3-1 and HA5526/4-2). This paper uses the Sample of Integrated Labour Market Biographies (SIAB) (Version 1975-2014). Data access was provided initially via onsite use at the Research Data Centre (FDZ) of the German Federal Employment Agency (BA) at the Institute for Employment Research (IAB) and subsequently through remote data access.
} 


\section{Introduction}

Policy interventions frequently influence labor supply. Large labor supply changes may have important effects on labor costs for establishments, thereby affecting labor demand. A prominent example of a labor cost shock is the introduction of binding minimum wages (Card and Krueger, 1994; Bruttel et al., 2018; Caliendo et al., 2019), and examples of external labor supply shocks are local migration waves induced by political changes (Dustmann et al., 2017) or the introduction of workfare, which is the requirement that everybody who receives social benefits has to work full-time (Peichl and Siegloch, 2012). In this paper, we focus on the impact of labor demand on the labor market reactions of older women on a pension reform with an increase in labor supply.

Since the 1990s, most OECD countries have reversed their retirement policies and started to encourage longer working lives to alleviate the decline of the working age population (overview in Börsch-Supan and Coile, 2018). In addition to tighter qualifying conditions and increases in the retirement age, policy makers have introduced actuarial deductions for early retirement. These deductions have increased the financial incentives for older employees to work longer and to postpone retirement. Employers with workers affected by these reforms have faced a labor supply shock because their older employees want to work longer than previously planned. In general, older employees have high earnings relative to their productivity compared with their younger co-workers (Hellerstein et al., 1999; Aubert and Crépon, 2003). Therefore, an extension of working life can induce a labor cost shock in addition to the adaption costs for employers that keep older workers in employment longer than expected.

In our analysis, we focus on the 1992 pension reform in Germany that increased the normal retirement age (NRA) gradually from 60 to 65 for several early retirement options and introduced deductions in pension entitlements for early retirement for women born after December 1939. Pension eligibility age (early retirement age; ERA) for the pension forms affected remained constant at age 60 . Therefore, the reform introduced financial incentives to increase labor supply between the ERA and NRA. To identify effects of the reform on labor market outcomes, we follow Engels et al. (2017) and use the exogenous variation in pension entitlements.

We use large administrative social security data from the Institute for Employment Research (Sample of Integrated Labor Market Biographies; SIAB) that are representative of the German labor market. These data include daily information on the full working history of individuals. Thus, we can calculate pension entitlements and eligibilities for different early retirement options. The data set also allows the first analysis of partial retirement, an important early retirement option that was introduced with the 1992 pension reform (Brussig et al., 2009). Most importantly, the SIAB provides detailed employer- 
specific information that enables us to analyze heterogeneities in the reactions of employees among employer types.

In line with previous studies, we show that pension deductions for early retirement increase the labor market attachment of older employees between ERA and NRA. Deductions postpone exit from the labor market and have a positive effect on employment, unemployment, and partial retirement incidence. In addition, our empirical analysis shows that labor market effects of the reform depend on the type of employer the employee works for before retirement. We show that employers with a high number of older employees compared with the number of newly hired young employees, employers in sectors with a high share of collective bargaining agreements, and employers in sectors with few investments in research and development (R\&D) are more responsive to their employees' demand to stay longer in employment. Responsiveness means that employers allow older women to stay longer with the employer via partial retirement after the ERA. In less responsive firms employees leave employment as early as before the reform, triggering longer unemployment spells after the ERA.

Our study is related to the sizable literature analyzing the labor market effects of pension reforms. Most of these studies focus on the supply side determinants of the labor market changes induced by the pension reforms. ${ }^{2}$ The role of employers on the labor market effects have been largely neglected (Rabaté, 2017). ${ }^{3}$ The literature so far therefore has incorrectly assumed autonomy of older employees on how and when to exit employment and a perfectly elastic labor demand (Peichl and Siegloch, 2012). We contribute to the literature taking into account that labor market decisions of older employees are jointly made by employers and employees. The reaction of employers to changes in labor supply is not perfectly elastic and some employers use the options at their disposal to thwart the incentive effects of the pension reform aimed at longer employment of older employees. Our theoretical hypotheses can explain which employer types are more responsive to the preferences of their employees.

The paper is organized as follows. In Section 2, we provide information about the German pension system and the 1992 pension reform. In Section 3, we discuss the role of the employer in the labor market effects of the pension reform and derive testable hypotheses on how employer characteristics may affect the labor market behavior of older employees. In Section 4, we introduce the data and present descriptive evidence. Our identification method is explained in Section 5. The labor market

\footnotetext{
2 Examples include Krueger and Pischke (1992); Duggan et al. (2007); Martins, et al. (2009); Mastrobuoni (2009); Coe and Haverstick (2010); Hanel and Riphahn (2012); Staubli and Zweimüller (2013); Vestad (2013); Atalay and Barrett (2015); Brinch et al. (2015); Lalive and Staubli (2015); Hernæs et al. (2016); or Manoli and Weber (2016).

3 Examples of papers that examine the labor demand effects of pension reforms include Bellmann and Janik (2007); Martins et al. (2009); Kondo (2016); Boeri et al. (2016); Bovini and Paradisi (2017); Vigtel (2018); Hakola and Uusitalo (2005); Hallberg (2011); Bello and Galasso (2015); Rabaté (2017).
} 
effects of the pension reform are presented in Section 6 . Section 7 shows the impact of labor demand on the effects. Section 8 concludes the paper.

\section{Institutional background}

\section{The German pension system}

Statutory public pension insurance is compulsory for all private and public sector employees and some groups of self-employed people. It provides old-age pensions and disability pensions and is the most important income source for the elderly, accounting on average for about two thirds of their gross household income. Depending on the length of the career and other conditions, the pensionable age varied between 60 and 65 for the cohorts for 1937-1944 analyzed in our study.

The focus of our paper is on the most important early retirement path for women: the pension for women (Altersrente für Frauen). This pension allowed women to retire at the age of $60 .{ }^{4}$ To be eligible for this pension, 15 years of contributions were required, of which at least 10 years must have been after the age of 40 . According to our data and consistent with Engels et al. (2017), about $60 \%$ of all women were eligible for this pension at the age of 55 . We only include women eligible for the pension for women in our sample to derive the treatment effect on the treated because the pension reform increased the NRA for this pension.

Women who were eligible for the pension for women had the statutory right to retire whenever they wanted after the ERA; therefore, they could extend their employment after the ERA autonomously and without the consent of their employer. There were two main alternative early retirement options: partial retirement ${ }^{5}$ and early retirement after unemployment. The ERA was the same for all three retirement options. Almost all women eligible for the pension for women were also eligible for early retirement after unemployment and partial retirement. ${ }^{6}$

From the perspective of the employee, the option to exit employment even before the ERA was the main advantage of becoming unemployed or entering partial retirement before retiring early. The maximum unemployment spell for older employees was 32 months, and thus the earliest employment exit was 57 years and four months for those eligible for the pension for the unemployed. ${ }^{7}$ In many

\footnotetext{
${ }^{4}$ In principle, it was possible to continue working after early retirement. However, for those in early retirement who continued working, pension benefits were withdrawn at relatively high rates. Consequently, only a negligible fraction of women worked while receiving a pension.

${ }^{5}$ This early retirement option was called "old age pension for persons under a progressive retirement plan".

${ }^{6}$ To be eligible for early retirement after unemployment and partial retirement, an employee needed at least 15 years of contributions and at least 8 years of compulsory contribution periods in the last 10 years before early retirement. Therefore, the eligibility requirements for the three pension forms were similar.

${ }^{7}$ The minimum unemployment spell to be eligible for early retirement after unemployment was 52 weeks. This requirement is not relevant for our sample because all women could enter the pension for women after reaching the ERA even if their unemployment spell was shorter than 52 weeks.
} 
cases, employer and employees may have colluded in reaching a mutual dismissal agreement, including a severance payment or voluntary compensation paid by the employer. However, there were several disadvantages of unemployment before early retirement compared with directly entering the pension for women. Unemployment benefits were about $60 \%$ of previous net earnings, and pension claims collected during unemployment spells were accordingly lower than during earnings spells. Collecting unemployment benefits before retirement also attracted social stigma and was considered by many as an undignified exit from work (Hetschko et al., 2014). Finally, it was uncertain whether and for how long labor offices withdrew unemployment benefits after a mutual agreement (Oswald, 1999). ${ }^{8}$

We can assume that in several cases unemployment was triggered by a dismissal against the will of the older employee. Here, the employee usually sued the employer before a labor court and obtained a severance payment ex-post, but almost never did the employee obtain re-employment (Jahn, 2009). The size of severance pay mainly was determined by the size of the employer (employers with more than five employees were subject to dismissal protection and employees had more rights), applicability of a collective bargaining agreement, the fairness of the dismissal, the tenure of the dismissed, and social criteria protecting the employee from dismissal (Schmähl, 2003; Jahn, 2009).

Partial retirement also allowed exit from employment before the ERA. Individuals could choose the block model ${ }^{9}$ that was characterized by two periods of equal length: in the first half, the employee worked full-time (active period) and in the second half, the employee was completely released from work (passive period) (Kirchner and Mittelhamm, 2010; Bundesagentur für Arbeit, 2015; Huber et al., 2016). With a standard partial retirement arrangement spanning 5 years (Kaldybajewa and Kruse, 2007), employees could exit employment as early as 57.5 years old when entering retirement at their ERA. We do not know which partial retirement mode was chosen because in the block model, the SIAB reports the fictitious end of the labor market spell instead of the de facto labor market exit date when the working hours are reduced to zero in the passive phase. However, on average about $90 \%$ of older employees chose the block model (Brussig et al., 2009; Wanger, 2009). The main disadvantage of partial retirement before early retirement from the employees' point of view was that they had to accept earnings reductions. The employer was bound by law to increase the current salary by at least $20 \%$ during partial retirement and wage earnings in excess of $50 \%$ of prior earnings were exempt from income taxes. Employers also had to pay additional pension contributions of at least $70 \%$ of the prepartial retirement earnings. Some collective agreements, for example, in the construction industry,

\footnotetext{
${ }^{8}$ Mutual agreements before dismissals often led to a blocking period for unemployment benefits of between 12 weeks and 6 months and a reduction in the maximum duration of unemployment benefits from 32 to 24 months (Jahn, 2009).

${ }^{9}$ The other option was the so-called 'continuity model', in which working hours were reduced (e.g., working half-days) during the entire partial retirement period.
} 
just included the legal minimum rules. In some collective agreements, for example, in the chemical industry, more generous rules than the legal requirements were fixed (Wanger, 2009). As a consequence, average earnings during partial retirement were about three quarters of the previous gross salary (Klammer and Weber, 2001) and pension entitlements accrued at a minimum of $90 \%$ of the rate obtained under full-time work (Berg et al., 2015). The generous financial compensation offered for partial retirement is not accidental. In contrast to a dismissal, the employers could not force employees into partial retirement. If an employer wanted an older employee to enter partial retirement it had to be willing to offer a financially attractive partial retirement package.

\section{Pension benefits before and after the 1992 pension reform}

Pension benefits are calculated based on a points system considering the entire earnings history of a person. A pension point is calculated annually by dividing the contributor's earnings by the average earnings of all contributors. There is a contribution assessment limit which is about twice the average (two pension points). In addition, pension entitlements may be acquired during other periods, such as unemployment, childcare, and informal care. There is no minimum pension.

Before the introduction of actuarial deductions in 1992, the pension benefits were calculated as the product of the sum of pension points at retirement and the pension point value in year $t$ by

Pension $_{t}^{\text {pre92 }}=\left(\sum_{a=\text { age }}^{\text {ret.age }}\right.$ pension point $\left.{ }_{a}\right) \times$ pension point value $_{t}$.

The pension point value is indexed to earnings growth and adjusted annually. Full pension benefits could be claimed before reaching the statutory retirement age of 65 years without actuarial deductions for early retirement. The reform in 1992 introduced actuarial deductions for early retirement. Starting with cohort 1940, the NRA was raised by 1 month from age 60 to 65 , depending on the month and year of birth of the individual. The access factor, $D$ (Zugangsfaktor), which accounts for the deductions and reduces pension benefits by $0.3 \%$ per month a person is retired before reaching the NRA, was added to the pension-benefits formula,

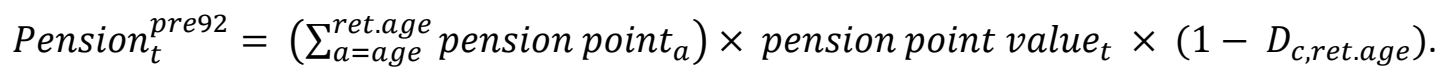

The factor $D$ depends on the month of birth, $c$, and retirement age. The NRA for the pension for women varied across cohorts born between January 1940 and December 1944. For example, if a woman born in December 1940 retired at the ERA in December 2000, D was 0.036 and her pension would be permanently reduced by $3.6 \%$. If she retired six months later, $D$ would be 0.018 . For a woman born one month later in January 1941, the deduction at the ERA was 3.9\%. The maximum deduction, 
incurred when retiring at the ERA, amounted to $18 \%$ for women born in December 1944 . The variation across month-of-birth cohorts and age is exploited in the empirical analysis.

The 1992 pension reform also introduced deductions for retirement after the ERA for both bridge options. The NRA was increased from age 60 to 65 , starting with cohort 1937. The NRA accordingly already reached the regular retirement age for cohort December 1942. Therefore, pension deductions for the pension after unemployment and after partial retirement were higher than deductions for the pension for women for each given retirement age before the NRA for all women until cohort 1945. We include in our sample only women eligible for the pension for women, and hence the NRA for the pension for women is the relevant age for calculating pension reductions. All the women, regardless of whether their last labor market spell was employment, partial retirement, or unemployment, had an incentive to use the pension for women as their early retirement venue. As a consequence, almost all women in partial retirement or unemployment finally used the pension for women (Deutsche Rentenversicherung Bund, 2018).

\section{Financial incentives of the pension reform}

The pension reform introduced deductions for retirement between the ERA and NRA. Therefore, we expect that employees were interested in exiting the labor market later than before the reform. The prolongation of labor market participation should increase with birth cohort in line with the increase in the difference between the NRA and ERA, and thus be greater for young cohorts. There is a clear ranking in employee preference on how to prolong labor market participation after the ERA. The most financially advantageous option is regular employment subject to social benefits. The second-best option is to remain in partial retirement after the ERA. The worst option is to stay longer in unemployment after the ERA if the woman was dismissed before or after the ERA (Kaldybajewa and Kruse, 2007).

The demand of establishments for older employees was unchanged by the pension reform and employers were forced away from their most efficient labor allocation by prolonging employment of older employees. Retaining older employees longer also resulted in some younger employees who were intended to replace the older workers doing another job within the employer, not being hired, or even being dismissed (Boeri et al., 2016). Employees eligible for the pension for women had the statutory right to decide when to enter retirement after the ERA. Thus, employers had to bargain actively with their employees if they wanted to avoid a prolongation of employment as a reaction to pension deductions. Employers' influence on the exit age from employment was clearly higher when they offered partial retirement or threatened dismissal. 
Employer autonomy in determining when the employee enters the passive phase of the partial retirement (i.e., exit from employment) was more constrained by legal rules than the time of the dismissal. The duration of partial retirement was fixed in most collective agreements (Wanger, 2009; Berg et al., 2015); thus, the employer could only determine the entry date into partial retirement, but generally not the duration of the partial retirement period. When the employer allowed a later exit from partial retirement, this usually also meant a later exit from employment and higher adaptation costs.

From the employer's perspective, a dismissal was generally financially more attractive than partial retirement (Schmähl, 2003). Besides the severance pay and other possible compensations necessary to obtain the employee's agreement for a dismissal, the firms faced almost no further costs when they dismissed their older employees. For partial retirement, employers had to form accruals for the passive phase of the block model and pay higher hourly wages for the entire period of partial retirement. Sample calculations of the distribution of costs for a typical partial retirement and pension after unemployment by Oswald (1999) demonstrate that partial retirement was substantially more expensive for the employer than a dismissal ceteris paribus.

In summary, the 1992 pension reform induced older women to stay longer in the labor market after the ERA. The pension for women gave them a statutory right to stay after ERA and we should observe a later exit from employment after the ERA. Employers had the option to dismiss their older employees or send them into partial retirement. Both bridge options gave the employers a stronger influence on the time the employee left employment. Employers responsive to the interests of their employees offered partial retirement as an alternative to longer employment. These employers allowed a shift of the exit from partial retirement spell with pension deductions to make this option attractive. Employers not responsive to the interests of their employees dismissed their employees then with or without consent. A dismissal before the ERA always increased the unemployment spell after the ERA with pension deductions.

\section{Labor demand effects on the labor market for older employees: Theoretical background}

We explain which groups of employers should be more responsive than others given the exogenous increase in labor supply of older women.

Hypothesis 1: Responsiveness is higher at employers that do not mainly hire young employees.

The substitution between older and prime-age employees is more flexible than between older and young employees (Boeri et al., 2016). Therefore, we assume that it is harder for employers that mainly 
hire young employees instead of older employees to prolong employment of older employees. In addition, a high share of young employees in all hires may indicate the presence of an internal labor market characterized by entry points reserved for young inexperienced employees who are offered promotion ladders within the hierarchies of their employers (Gibbons and Waldman, 2006). When older employees stay longer than expected, this might reduce the motivation of young employees who are waiting for senior positions to become vacant (Backes-Gellner and Veen, 2013). Consequently, employers that offer internal labor markets may not be willing to allow prolonged employment and partial employment after the ERA, and may instead prefer to dismiss their older employees because retaining older employees reduces the promotion and employment chances of their young job entrants. Thus, responsiveness should be lower for employers with a high share of older employees in all newly hired young employees.

\section{Hypothesis 2: Responsiveness is higher at employers not subject to dismissal protection.}

Dismissal protection legislation increases costs to dismiss older employees (Jahn, 2009). Therefore, we expect firms subject to dismissal protection to offer partial retirement instead of dismissing employees. They also have a higher incentive to shift entry into unemployment because they have to compensate their dismissed employees for longer unemployment spells or pension deductions after the reform.

\section{Hypothesis 3: Responsiveness is higher at employers without collective bargaining agreements.}

Many collective bargaining agreements include additional rules for employment protection of older employees. These rules make dismissing older employees more expensive or even impossible for employers subject to these agreements. In addition, unions favor partial retirement as an alternative to unemployment as a bridge option into retirement (Berg et al., 2015). Unions and works councils also support older employees in their bargaining efforts with their employers to prolong employment or enter partial retirement after the ERA and help employers to organize the frictionless implementation of the complicated partial retirement legislation (Wanger, 2009). Therefore, we assume that employers subject to collective bargaining offer their older women partial retirement, increase employment in partial retirement after the ERA, and help their employees to avoid unemployment periods after the ERA.

Hypothesis 4: Responsiveness is higher for firms with low R\&D expenses.

Employers whose competitiveness depends on innovations might have a strong interest in replacing their older employees with younger employees. There is evidence that the workforce age structure is negatively related to firm-level innovativeness in Germany (Schneider, 2008). This observation has 
been explained by older employees working with outdated technological knowledge and having less cognitive flexibility and openness to absorbing new topics, as well as a general decline in creativity with age (Schmähl, 2003; Simonton, 2007). Ilmakunnas and Maliranta (2007) showed that in innovative sectors, such as the information and communication industry, the dismissal of employees who are older than 49 years increases innovation success. Schubert and Andersson (2015) found that firms with older employees can at least partially compensate for the decrease in the number of innovations by increased substitution of older employees with younger employees. Employers with higher R\&D expenses may also prioritize creative tasks. Age-diverse workforces are positively related to creative task productivity because they have a larger pool of knowledge and a more extensive problem solving tool box (Backes-Gellner and Veen, 2013). Thus, employers with high R\&D expenses may try to increase age diversity by substituting older employees with newly hired younger employees. We therefore assume that employers with high R\&D expenses are less willing to offer partial retirement and longer employment for their older women and instead dismiss them when facing an increased labor supply of older women.

\section{Hypothesis 5: Differences among employer groups are larger for partial retirement and unemployment spells than for regular employment.}

Employers can decide whether and when to offer an older employee partial retirement or whether to dismiss an older employee. Older women have the statutory right to determine their exit from the labor market autonomously when they do not use these bridge options and stay in regular employment until the ERA. Therefore, we assume that differences among employer groups are larger for unemployment and partial retirement spell lengths than for employment spell length after the ERA.

\section{$4 \quad$ Data}

Our study is based on a large, high-quality administrative data set provided by the Federal Employment Agency in Germany (Bundesagentur für Arbeit). The data consist of a $2 \%$ sample of the population of the Integrated Employment Biographies from 1975 to $2014^{10}$ and contain daily information about employment and receipt of benefits according to the German Social Books II and III. We add the daily date of birth to the data set because the exact calculation of pension entitlements requires the birth date. ${ }^{11}$ Moreover, we link a rich set of establishment information from the IAB Establishment History Panel (BHP) to the individual employment history. Finally, we match the monthly regional

\footnotetext{
10 Onsite data access and subsequently remote data access was provided by the Research Data Centre (FDZ) of the German Federal Employment Agency (BA) at the Institute for Employment Research (IAB). A detailed description of the SIAB can be found in Antoni et al. (2016).

${ }^{11}$ We are grateful to Philip vom Berge and Dana Müller from the FDZ at the IAB for merging this information as part of the Custom Shaped Administrative Data for the Analysis of Labor Market (CADAL) project.
} 
unemployment rates from the Federal Employment Agency to the place of work and calculate the average annual regional unemployment rates between 1991 and 2014 for each region.

In contrast to previous studies based on pension insurance data (Engels et al., 2017), we can identify separately the effect of the pension reform on employment and partial retirement. ${ }^{12}$ When we calculate the exit from employment for those in partial retirement, we add half of the partial retirement period because virtually all older women eligible for the pension for women chose the block model version of partial retirement . To calculate the spell length of partial retirement, we use the full spell length because the end of the passive phase determines the labor market exit, and thus the pension deductions.

Our data set does not include relevant characteristics of the pension insurance, such as pension entitlements or eligibility. Thus, we calculate individual pension entitlements and identify eligibility criteria for old-age pensions and the corresponding statutory retirement dates (NRA and ERA) according to Pfister et al. (2018) and Lorenz et al. (2018). ${ }^{13}$

\section{Estimation sample}

We consider the individual monthly employment biographies of women born between 1937 and 1944 who were between 55 and 65 years old. Similar to Engels et al. (2017), in our sample, we include only women who fulfill the requirements for the old age pension for women at the age of 55 . Our estimates can be interpreted as the average treatment effect on the treated of the pension reform because all women were affected by the reform. In addition, we restrict our sample to West German ${ }^{14}$ women with a high labor market attachment. All women in our sample must have been in the labor market at the age of 59 (i.e., employed or registered unemployed), have been observable at least once before age $42,^{15}$ have had employer characteristics in their last employment spell, and have had gaps of no longer than 5 years in their labor market histories. ${ }^{16}$ These restrictions ensure that the women could decide freely whether to stay in the labor market at age 60 or postpone retirement because they had

\footnotetext{
${ }^{12}$ To the best of our knowledge, partial retirement spells can be identified only in the SIAB. In other data sets that have been used to study the labor market, the effects of pension reforms, such as the VSKT (Versichertenkontenstichprobe der deutschen Rentenversicherung, the Mikrozensus, or the SOEP (Sozio-oekonomische Panel), partial retirement cannot be separated from regular employment.

${ }^{13}$ Selected sample descriptive statistics are given in Appendix B.

${ }^{14}$ Labor market careers can only be observed in East Germany from January 1, 1991; therefore, eligibility for the pension for women cannot be calculated for East German women.

${ }^{15}$ We only observe labor market careers after January 1, 1975 and we cannot calculate the waiting period of 15 years for women. Therefore, we must assume that women who completed more than 10 years of compulsory contribution periods after age 40 also fulfilled the waiting period of 15 years. According to Lorenz et al. (2018), almost all women who fulfilled the 10-year requirement also fulfilled the 15 -year requirement.

${ }^{16}$ With respect to the whole of the eligible sample, we exclude about $29.6 \%$ of women for the restriction of labor market observation at age 59 , about $4.1 \%$ for completing the last employment subject to social security contributions before reaching the age of $55,7.4 \%$ for no labor market status before or at the age of $41,0.2 \%$ for no compulsory contribution in the last 10 years before leaving the labor market, and $5.8 \%$ for labor market gaps longer than 5 years.
} 
realistic chances of keeping their job, switching to another job, or staying in unemployment until they reached the NRA for the pension for women.

Our reduction of the sample to women who were eligible for the pension for women and those who were active in the labor market at age 59 has the advantage that we exclude all women who had relevant alternatives to the early retirement options we examine. The main channel to avoid pension deductions in Germany when retiring before age 60 was the pension for those with reduced earnings capacity. This pension allowed employees to immediately retire when they were not able to work anymore in their occupation (Berufsunfähigkeit/Erwerbsunfähigkeit). Average retirement age for those with reduced earnings capacity was around 53 for women born in the cohorts we focus on (Deutsche Rentenversicherung Bund, 2018). In other words, almost all women who used the pension with reduced earnings capacity left the labor market before age 59 (Lorenz et al., 2018). Thus, these women are not included in our sample. In addition, reduced earnings capacity had to be assessed in a medical exam, so it was hard to obtain without a cause. The only other channels for early retirement were the pension for the severely disabled and special pension schemes (miners and seamen). The options of obtaining disability status or becoming miners or seamen to avoid pension deductions can be excluded. Consequently, we assume that there is no substitution into other (unobservable) early retirement schemes as a reaction to the pension reform for women in our sample. After introducing the sample restrictions, we are left with 12,548 women and 765,428 person-month observations.

\section{Descriptive evidence}

Our descriptive analysis focuses on employment, unemployment, and partial retirement between ages 55 and 65 to capture the patterns of employees' labor market behavior in response to the pension reform. We show how these labor market outcomes vary by age and cohort. Figure 1 shows agespecific employment subject to social security contribution rates without partial retirement for the different cohorts. ${ }^{17}$ Before age 60 , the employment of the pre-reform cohorts 1937-1939 was higher than the employment of the cohorts 1940-1944 affected by the reform. The employment reduction before the ERA can be completely explained by a substitution of regular employment into the active phase of partial retirement (Fig. C2 in Appendix C). The fact that employment (regular plus active phase in partial retirement) before 60 is practically identical for all cohorts supports our hypothesis that there were no reform anticipation effects before the ERA (see also Riphahn and Schrader, 2019). However, we find a sharper drop in the employment rate for the pre-reform cohorts at age 60 . About $60 \%$ of all women eligible for the pension for women left employment at the ERA in the cohorts not affected by

\footnotetext{
17 We only consider employment that is subject to social security contributions and partial retirement because marginal employment has only been recorded since April 1999 in the data (Antoni et al., 2016).
} 
the pension reform. From age 60 to 65 , the gradual introduction of pension deductions for those who retired earlier than the NRA for the pension for women gradually increased employment after the ERA according to our theoretical considerations. However, the employment increase with cohort decelerated, suggesting that the pension deductions had a decreasing effect on employment rather than a linear effect. In addition, according to our hypotheses, the reform seems to have had almost no positive effect on employment beyond the NRA for the pension for women. For the cohorts 19401942 , employment rates after the NRA are similar to those of the cohorts not affected by the reform. For example, comparing employment after age 62 for cohort 1941 with cohorts 1937-1939, we get a similar employment pattern if we include the active phase of partial retirement, suggesting that the active phase of partial employment was extended gradually to periods after the ERA (Fig. C2 in Appendix $\mathrm{C}$ ). The positive employment effect induced by the pension reform therefore is only found for the time period between ERA and NRA.

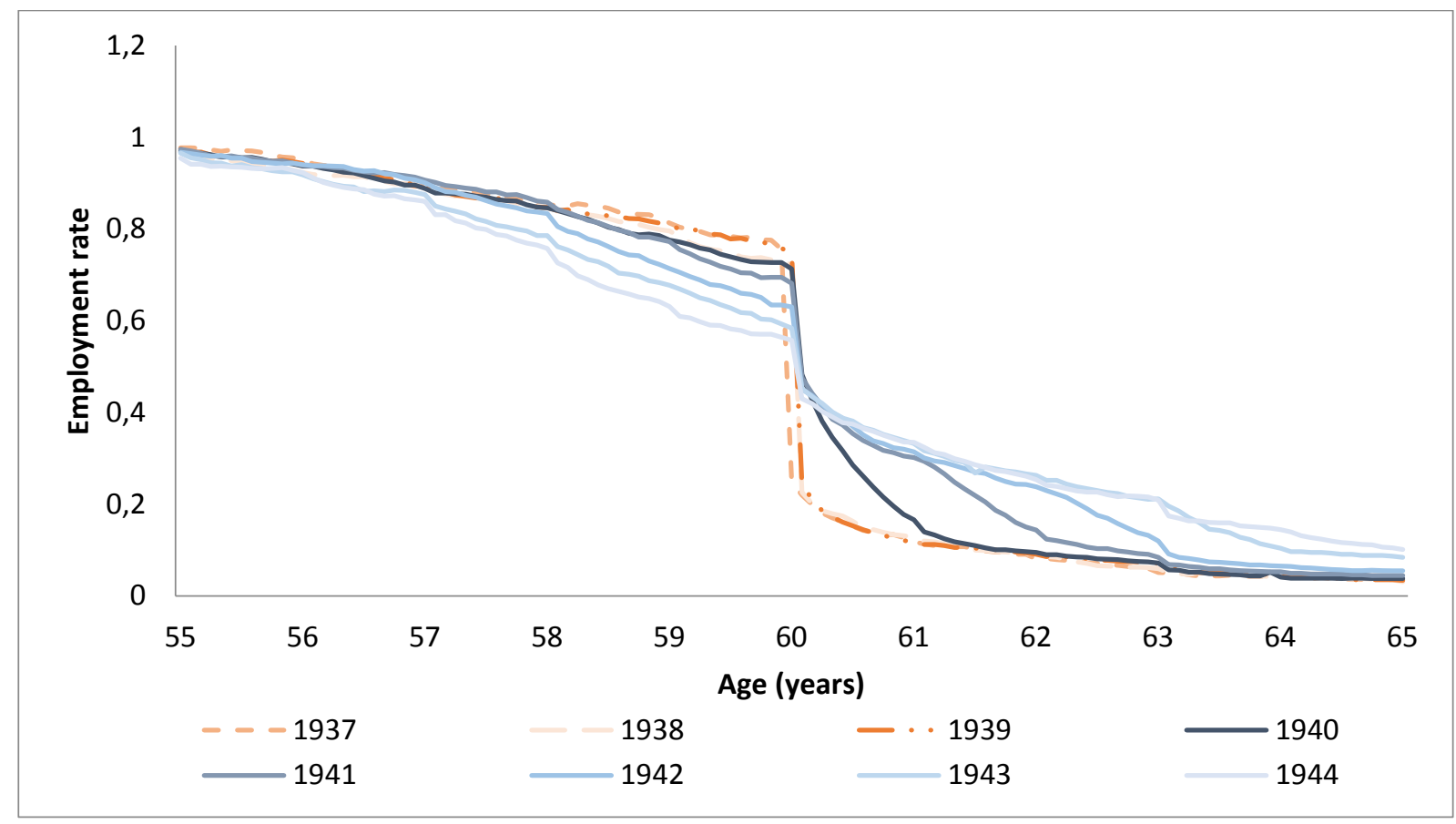

Fig. 1. Employment (employment subject to social security contributions without partial retirement) rates by age (monthly data) and cohort. Source: SIAB7514, own calculations.

The cohort-specific patterns of partial retirement rates, including the passive phase, are shown in Figure 2. The Partial Retirement Act provided the option of partial retirement as a bridge to retirement from 1996 onwards. ${ }^{18}$ During the first years after the introduction of partial retirement, employers could only offer the bridge option if they were subject to collective agreements that included partial

\footnotetext{
18 Before the reform, only the chemical industry had a specific partial retirement option in their collective bargaining agreements. Therefore, there are few cases of partial retirement reported for the cohorts 1937-1939. After 1998, the number of employees working in firms covered by partial retirement collective agreements dramatically increased (Berg et al., 2015).
} 
retirement (Berg et al., 2015). Accordingly, partial retirement incidence increased with cohort because the number of employers entitled to offer partial retirement was small initially. Figure 2 shows a gradual increase in partial retirement incidence from cohort 1940 onwards before and after the age of 60. Our calculations indicate that the pension reform led to the prolongation of partial retirement spells after ERA. After exiting partial retirement, most older women applied for the pension for women. As a consequence, partial retirement ending after the NRA for the pension for women was not attractive. Thus, we do not observe partial retirement after, for example, age 61 for cohort 1941 or age 62 for cohort 1942.

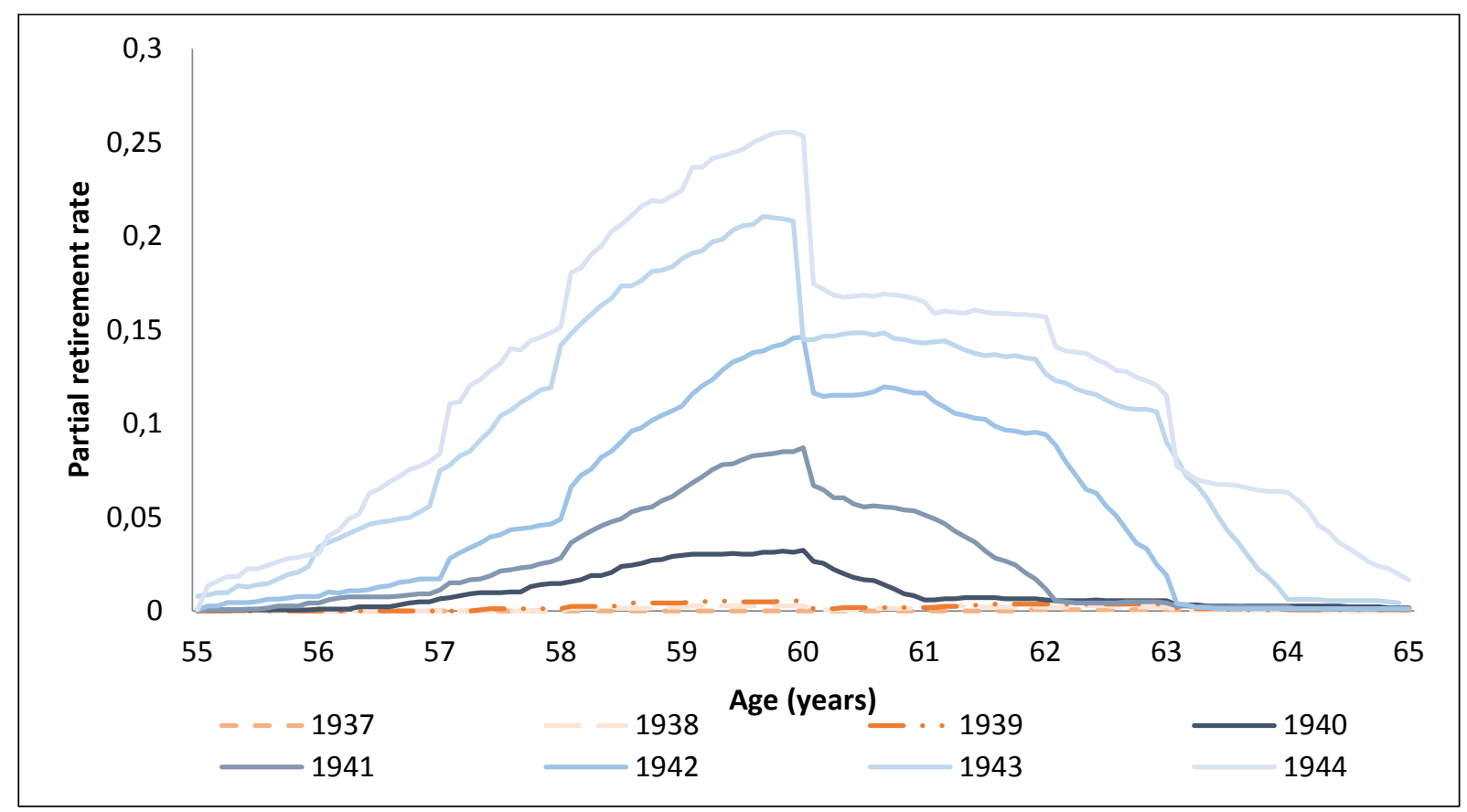

Fig. 2. Partial retirement rates by age (monthly data) and cohort. Source: SIAB7514, own calculations.

In Figure 3, the unemployment rates are displayed by cohort. The unemployment rates for the control cohorts (1937-1939) increased greatly before the age of 60 in line with the general increase in unemployment in West Germany from 1991 to 1997 of 7\% to 13\% (Bundesagentur für Arbeit, 2019). Many employers used dismissals of their older employees to meet their reorganization requirements externally during the recession (Schmähl, 2003). After 1998, the business cycle picked up and the pressure to reduce employment eased. There are few unemployment spells after age 60 in the control cohorts because all unemployed older women in our sample had the right to enter the pension for women by age 60 without deductions. According to our hypothesis, we observe a prolongation of unemployment spells between the ERA and the NRA. Unemployment is not attractive after NRA for those eligible for the pension for women. As a consequence, there is little unemployment after, for example, age 61 for cohort 1941 and age 62 for cohort 1942. 


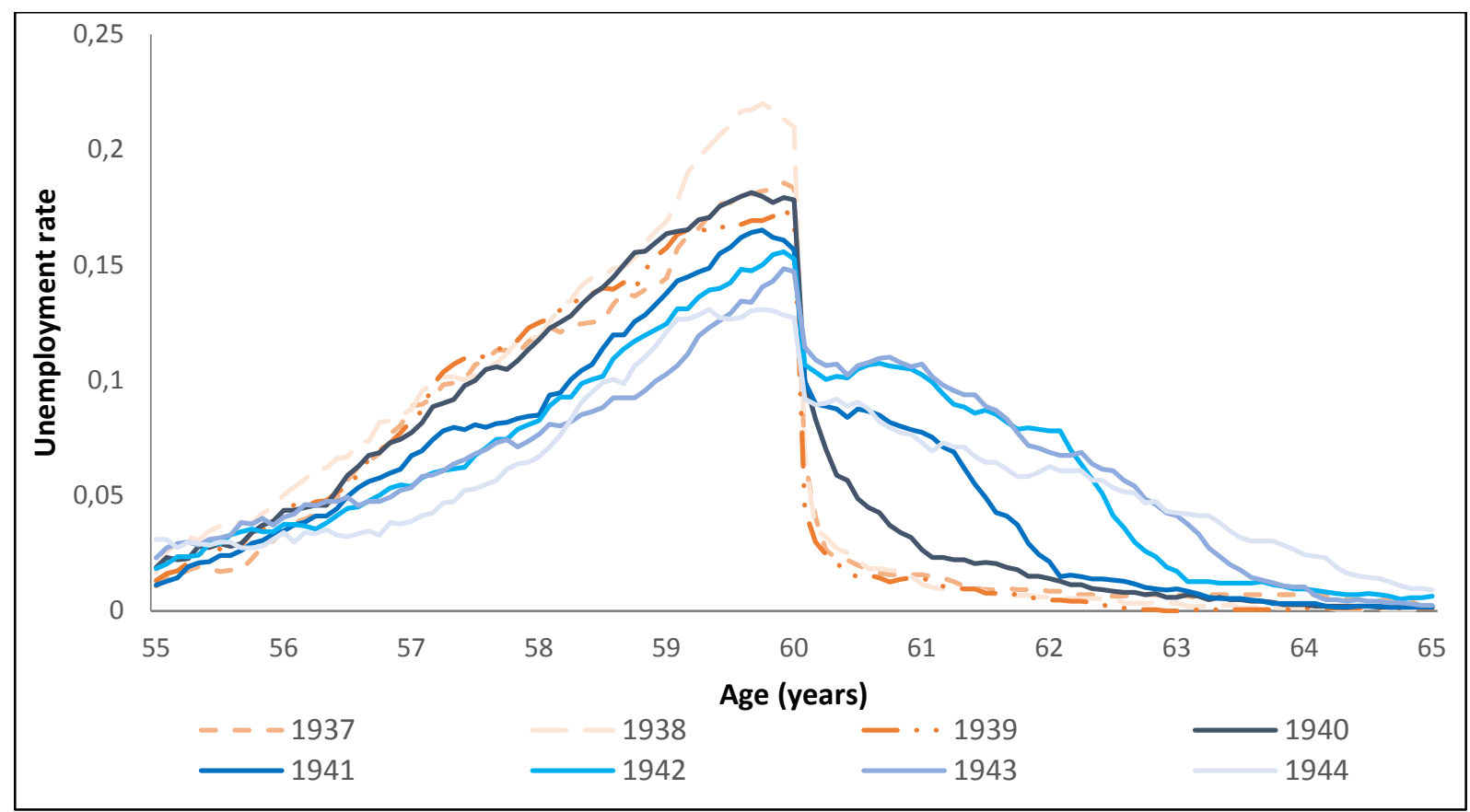

Fig. 3. Unemployment rates by age (monthly data) and cohort. Source: SIAB7514, own calculations.

In Figure $\mathrm{C} 1$ in Appendix $\mathrm{C}$, we report the labor market exit age by cohort. Permanent exit from the labor market is the fourth possible labor market state in addition to partial retirement, employment, and unemployment. Therefore, the shares in these four states add up to one. Analogously to the changes in employment and unemployment by cohort observed above, labor market exit prolongation is only observable between ERA and cohort-specific NRA for the pension for women. We do not know whether women directly entered retirement after leaving the labor market, and thus we cannot calculate the increase in retirement age from our data.

\section{$5 \quad$ Estimation method}

We analyze how employers responded to an exogenous labor supply shock of older women induced by a pension reform. To identify and quantify this effect for different groups of employers, we use the introduction of deductions for early retirement by the 1992 pension reform. Based on our theoretical hypotheses, we test whether the labor market effects induced by the pension reform differ among employer groups.

\section{Direct effects of deductions on employment outcomes}

To assess the direct effect of deductions on pension entitlements on age-specific labor market outcomes for different types of employers, we propose the estimation equations 
$y_{1 i t}=\alpha_{1}+\theta_{1 i t}+\lambda_{1 c}+\gamma_{1} D_{i t}+\beta_{1 x} X_{i t}+\beta_{1 y} Y_{j}+v_{1 j}+e_{1 i t}$ if $j \in$ employer group 1,

$y_{2 i t}=\alpha_{2}+\theta_{2 i t}+\lambda_{2 c}+\gamma_{2} D_{i t}+\beta_{2 x} X_{i t}+\beta_{2 y} Y_{j}+v_{2 j}+e_{2 i t}$ if $j \in$ employer group 2,

where groups of employers are defined according to our hypotheses. $y$ denotes employment, partial employment, or unemployment of individual $i$ at employer group 1 or 2 at age $t$. The main variable of interest, $D_{i t}$, measures the deductions on pension entitlements for those who enter early retirement with the pension for women. If $\gamma_{1}$ significantly differs from $\gamma_{2}$, the employer type influences the labor market outcomes of older women affected by the pension reform in addition to individual $X_{i}$ and employer $Y_{j}$ characteristics. In particular, in $X_{i}$ we include the SSW for planning age 55 to capture the individual employment and earnings history ${ }^{19}$, job exposure of the occupation in the last employment ${ }^{20}$, education level, and changes in the legislation for disability pensions and in the entitlement rules for unemployment insurance. ${ }^{21}$ Establishment-level controls include the mean imputed wage of all full-time employees, economic sector, establishment size, share of full-time and part-time female employees, share of full-time regular workers, share of trainees, share of full-time unskilled employees, share of full-time qualified employees, share of full-time highly qualified employees, share of employees aged 55-59, share of employees aged 60-64, mean age of the total full-time employees, and the regional unemployment rate. ${ }^{22}$ The inclusion of employer characteristics shows whether the labor market decisions of older women affected by the pension reform are influenced by the work force characteristics of their employer. Finally, to capture possible unobserved differences among employers in their treatment of older employees, we include establishment fixed effects, $v_{j}$. The identification of establishment-specific effects for the employment and partial retirement estimations is possible because we observe individuals with different deduction levels at the same establishment.

To account for age- and cohort-specific effects on the individual retirement decisions that are not directly related to the deductions, we include monthly age fixed effects $\left(\theta_{i t}\right)$ and monthly cohort fixed effects $\left(\lambda_{c}\right)$. As discussed in detail in Engels et al. (2017), the age and cohort-specific effect can be identified separately from the pension deductions because the 1992 pension reform affects cohorts at different ages. To identify the effect of deductions, we only need to assume that the age-specific effects on employment do not change among the cohorts after controlling for labor supply and labor

\footnotetext{
19 Because we measure the SSW at age 55, this variable is not affected by the pension reform and does not systematically vary among the different cohorts. For more details, see Appendix A.

20 To measure the job exposure in occupations, we use the job exposure matrices (JEM) from Kroll (2011) and match the JEM via the classification of occupations 2010 (Klassifikation der Berufe KLdB-2010) to our data.

${ }^{21}$ Detailed descriptive statistics about the individual characteristics are given in Appendix $B$.

22 Detailed descriptive statistics about the employer characteristics are given in Appendix B.
} 
demand factors for labor market behavior of older employees. This assumption is weaker than assuming that there are no general labor market differences among the cohorts because the cohortspecific effects would control for these differences. ${ }^{23}$

To obtain a single measure for the labor market consequences of the pension reform in months, we add the labor market effects of all employees affected based on cohort-specific age profiles (Engels et al., 2017). We report the sum of coefficients as our basic specification and show the average change in months in the outcome variables induced by increasing the NRA by 1 year (or pension deductions of $3.6 \%)$.

In general, it is difficult to separate labor supply and labor demand effects on labor market outcomes because employers and employees make joint decisions (Rabaté, 2017). However, we can identify the effect of labor demand. First, the deductions of pension entitlements for those who entered early retirement at the age of 60 or later do not differ among employers and they do not affect labor demand. Second, we control for the main individual drivers used to predict labor market behavior of older employees (Börsch-Supan et al., 2004; Börsch-Supan and Coile, 2018). Third, we include employer characteristics and establishment-specific effects, which account for heterogeneous sorting into different establishments. Finally, to account for specific sorting effects of the pension reform, namely, that employees choose their employer according to the expected labor demand flexibility, all employer characteristics are measured before women were affected by the pension reform. ${ }^{24}$

\section{Average effects of the pension reform}

\section{Direct effects of the pension reform on labor market outcomes}

The effects of the pension deductions on the labor market outcomes are displayed in Table 1. The main variables of interest are the cohort-specific pension deduction variables when leaving the labor market between the ERA and NRA of the pension for women. In column I, a linear effect of the deductions on labor market outcomes is imposed, whereas in column II, this assumption is relaxed by using indicator variables for different values of the deduction variable. In column III, we add employer characteristics and the regional unemployment rates plus establishment fixed effects.

\footnotetext{
${ }^{23}$ Engels et al. (2017) present descriptive evidence that the labor market behavior of the adjacent cohorts is similar, absent the changes induced by the pension reform.

${ }^{24}$ In our sample, most employees were already employed at the last employer of their career before the pension reform was discussed and introduced in 1997. During the discussion of the pension reform since 1992, there have been several surprising changes in the design and group of affected employees. Therefore, we can assume that there were hardly any anticipation effects for this reform (Riphahn and Schrader, 2019). In a robustness check, we restrict our sample to those employees who were already employed in 1991 at the last employer of their career. All results remain robust.
} 
For the simplest estimation specification, we find that a small pension deduction has sizeable effects on employment. On average, an increase in deductions by 0.3 to 3.6 percentage points (PP) increases employment between age 60 and 65, including the active phase of partial retirement, by 1.3 PP (column I). The employment effect almost doubles for the group with maximal deductions. We find a somewhat stronger positive effect of the pension reform on employment than Engels et al. (2017) (Table 1). This difference is consistent with our positive sample selection of women who are either employed or registered unemployed at age 59. Therefore, the chances of working beyond age 60 are higher in our sample than for all women eligible for the pension for women. Controlling for all individual and firm-specific characteristics, we find that women facing deductions in their pension entitlements up to $3.6 \%$ and up to $18 \%$ have 15.8 and 27.0 PP higher employment, respectively, than women without deductions after the ERA (column III). Unemployment incidence increases slightly with the deductions up to deductions between $11.1 \%$ and $14.4 \%$, and then decreases slightly again. The effect of the pension reform on unemployment is smaller in our sample than in Engels et al. (2017), but has the same concave shape with respect to deductions. The difference between partial retirement and unemployment is mainly driven by the stronger effects of higher pension deductions on partial retirement. In the group with maximum deductions, partial retirement is 14.7 PP higher.

The individual drivers of labor market decisions of older employees all have the expected signs (BörschSupan et al., 2004; Engels et al., 2017). ${ }^{25}$ Employment and unemployment after the ERA is smaller for employees with high pension entitlements. The negative sign indicates that leisure is a normal good and that older women with higher non-labor income substitute employment with retirement. All labor demand estimates are highly significant and do not change substantially after controlling for regional unemployment and employer characteristics. Including the establishment fixed effects increases the estimated effects of the pension reform on employment and partial retirement.

Overall, the 1992 pension reform led to a strong employment increase of around 1.8 months per year after the ERA (Table 1). Unemployment after age 60 increased by more than half a month per year, and partial retirement increased by 0.8 months. Therefore, the reform effects were sizeable and dominated by a prolongation of employment, consistent with the financial incentives set by the pension deductions.

\footnotetext{
${ }^{25}$ See Table D1 in the Appendix.
} 


\begin{tabular}{|c|c|c|c|c|c|c|c|c|}
\hline & \multicolumn{3}{|c|}{ Employment } & \multicolumn{3}{|c|}{ Partial retirement } & \multicolumn{2}{|c|}{ Unemployment } \\
\hline & I & II & III & I & II & III & 1 & II \\
\hline No deductions & Ref. & Ref. & Ref. & Ref. & Ref. & Ref. & Ref. & Ref. \\
\hline \multirow[t]{2}{*}{$0.3-3.6$} & $0.128 * *$ & 0.127 & $0.158 * *$ & $0.046 * *$ & $0.046 * *$ & $0.059 * *$ & $0.042 * *$ & $0.042 * *$ \\
\hline & $(0.004)$ & $(0.004)$ & $(0.005)$ & $(0.003)$ & $(0.003)$ & $(0.003)$ & $(0.002)$ & $(0.002)$ \\
\hline \multirow[t]{2}{*}{$3.9-7.2$} & $0.151^{* *}$ & $0.152^{* *}$ & $0.185^{* *}$ & $0.073 * *$ & $0.073 * *$ & $0.092 * *$ & $0.055^{* *}$ & $0.055^{* *}$ \\
\hline & $(0.005)$ & $(0.005)$ & $(0.006)$ & $(0.003)$ & $(0.003)$ & (0.004) & $(0.003)$ & $(0.003)$ \\
\hline \multirow[t]{2}{*}{$7.5-10.8$} & $0.189 * *$ & $0.192 * *$ & $0.225^{* *}$ & $0.100 * *$ & $0.099 * *$ & $0.120 * *$ & $0.058 * *$ & $0.058 * *$ \\
\hline & $(0.006)$ & $(0.006)$ & $(0.007)$ & $(0.004)$ & $(0.004)$ & $(0.005)$ & $(0.004)$ & $(0.004)$ \\
\hline \multirow[t]{2}{*}{$11.1-14.4$} & $0.221^{* *}$ & $0.225^{* *}$ & $0.257^{* *}$ & $0.118 * *$ & $0.118 * *$ & $0.135 * *$ & $0.066 * *$ & $0.064 * *$ \\
\hline & $(0.008)$ & $(0.008)$ & $(0.009)$ & $(0.006)$ & $(0.006)$ & $(0.007)$ & $(0.005)$ & $(0.005)$ \\
\hline \multirow[t]{2}{*}{$14.7-18.0$} & $0.245^{* *}$ & $0.251^{* *}$ & $0.270 * *$ & $0.132 * *$ & $0.131 * *$ & $0.147 * *$ & $0.060 * *$ & $0.058^{* *}$ \\
\hline & $(0.012)$ & $(0.012)$ & $(0.013)$ & (0.009) & $(0.008)$ & $(0.010)$ & $(0.007)$ & $(0.007)$ \\
\hline \multirow[t]{2}{*}{ SSW } & $-0.04 * *$ & $-0.05^{* *}$ & $-0.06 * *$ & $0.02 * *$ & $0.01 * *$ & -0.005 & $-0.01 * *$ & $-0.006 * *$ \\
\hline & $(0.005)$ & $(0.005)$ & $(0.01)$ & $(0.003)$ & $(0.003)$ & $(0.01)$ & $(0.002)$ & $(0.002)$ \\
\hline Cohort effects & Yes & Yes & Yes & Yes & Yes & Yes & Yes & Yes \\
\hline Reform effects & Yes & Yes & Yes & Yes & Yes & Yes & Yes & Yes \\
\hline $\mathrm{X}$ variables & Yes & Yes & Yes & Yes & Yes & Yes & Yes & Yes \\
\hline Y variables & No & Yes & Yes & No & Yes & Yes & No & Yes \\
\hline Establishment fixed effects & No & No & Yes & No & No & Yes & No & No \\
\hline Effect of a 1-year NRA increase & & $1.807^{* *}$ & & & $0.789 * *$ & & & $0.597^{* *}$ \\
\hline in months & & $(0.179)$ & & & $(0.053)$ & & & $(0.056)$ \\
\hline$N$ & 765,428 & 765,428 & 611,351 & 765,428 & 765,428 & 611,351 & 765,428 & 765,428 \\
\hline Pre-reform mean & 0.098 & & & 0.001 & & & 0.011 & \\
\hline$R^{2}$ & 0.166 & 0.219 & 0.671 & 0.094 & 0.113 & 0.533 & 0.049 & 0.062 \\
\hline
\end{tabular}

Tab. 1. Direct effects on labor market outcomes. Notes: Employment includes the active phase of partial retirement. The number of observations, $N$, is 765,428 for columns I and II and 611,351 for column III. SSW is calculated with the planning age of 55 at the age of 59 . SSW is multiplied by 1,000,000. In specification I, we control for individual characteristics. In column II, we additionally control for employer characteristics, and in column III, we estimate establishment fixed effects. Standard errors in parentheses are clustered on the individual level. Significance levels: ${ }^{*} p<$ $0.05, * * p<0.01$. The pre-reform mean is calculated for the pre-reform cohorts 1937 to 1939 . Source: SIAB7514, own calculations. 


\section{The role of labor demand}

In this section, we examine how employer characteristics influence the reaction of employees to financial incentives of the pension reform. ${ }^{26}$ In Table 2, we report the reform effects on labor market outcomes separately for employees in establishments with high or low average shares of older worker inflow compared with the share of young worker inflow. More specifically, we calculate the average share of newly hired employees older than 55 with respect to new hires younger than 30 over the period in which we observe the last employer before retirement up to the year 1999. Employers with an average share of older worker inflow to young worker inflow above the $75^{\text {th }}$ percentile are defined as "high" and employers with an average share below the $25^{\text {th }}$ percentile are defined as "low". According to hypothesis 1 , employers with a large share of older worker inflow compared with young worker inflow are more responsive to the labor supply shock; the employment and partial retirement increases after the ERA are larger and the unemployment increases are smaller. The differences among employer groups are strong and significant for larger deductions with respect to unemployment and partial retirement. Women who receive deductions between $7.5 \%$ and $10.8 \%$ increase their unemployment by 7.5 PP if they work in firms with a low share and by 4.7 PP if they work in firms with a high share of newly hired older employees. We also find these significant differences for deductions between $11.1 \%$ and $14.4 \%$. Partial retirement increases are stronger for high share firms in almost all deduction groups.

We also compare the labor market effects of the pension reform for firms with fewer than five employees compared with firms with five to 20 employees. Employers with fewer than five employees are exempted from the dismissal protection rules that specifically protect employment of older employees. According to hypothesis 2, older women working in establishments subject to dismissal protection can stay longer in employment and in partial retirement, and they do not have to increase their unemployment spells as much (Table 3). ${ }^{27}$ The largest differences are again found for the changes in partial retirement incidence. However, not all differences are significant, and thus dismissal protection does not appear to play as important a role in employer behavior as hypothesized.

We cannot observe directly whether an employer is subject to a collective bargaining agreement or not. Therefore, we split the employers into two groups: employers in the three sectors with the highest

\footnotetext{
${ }^{26}$ We also include establishment fixed effects to test the robustness of our results. The results of the establishment fixed effect estimations are in line with the results presented in Tables 2 to 5 . For the unemployment rate, we cannot estimate establishment fixed effects because the unemployed do not have an establishment identifier.

27 If we divide the employer sample in the $75^{\text {th }}$ percentile and the $25^{\text {th }}$ percentile of establishment size or extend the group with dismissal protection to all employers larger than five employees, we obtain significant differences for unemployment and partial retirement spells. However, it seems highly probable that for the large employers group, unobservable factors in addition to dismissal protection play a role in the pension reform effects.
} 
collective bargaining coverage and those in sectors with the lowest collective bargaining coverage. ${ }^{28}$ We find that in line with hypothesis 2 , firms in sectors with high collective bargaining coverage allow women to stay longer in employment, do not force them to increase their unemployment by dismissing them before the ERA, and offer them a later exit from partial retirement (Table 4).

We also sort economic sectors by their R\&D intensity. We categorize all employers in the three sectors with the highest R\&D expenses into the "high R\&D expenses" group and all employers in the three sectors with the lowest R\&D expenses into the "low R\&D expenses" group. ${ }^{29}$ We find that according to hypothesis 4 , employers in sectors with high R\&D expenses are less responsive to the demands of older women to stay in employment longer. In this group of employers, the rate of older women staying in partial retirement is significantly smaller in all deductions groups and they are significantly stronger in unemployment. There is no difference in employment incidence between both employer groups. Hence, firms in sectors with high R\&D expenses seem to have a stronger incentive to rejuvenate their workforce by dismissing their older women or offering partial retirement spells that end before the NRA than firms in sectors that are less dependent on R\&D efforts (Table 5).

According to hypothesis 5, significant differences among employer groups are observed mainly for partial retirement and unemployment spells. The employment spells after ERA primarily come from employees who take the pension for women directly after employment as their early retirement option because older women using one of the two bridge options have usually exited employment before the ERA. However, entering the pension for women directly from regular employment cannot be influenced by employees, and thus there are hardly any differences in employment after the ERA for women without bridge option among employer types (compare Appendix E).

\footnotetext{
${ }^{28}$ The three sectors with the highest collective bargaining coverage in the year 2014 are energy provision; public services, defence, and social security; and education. The three sectors with the lowest collective bargaining coverage are agriculture and forestry; trade, maintenance, and repair of motor vehicles; and other professional, scientific and technical services (own calculation, based on German Statistical Office, series earnings structure (Verdienststrukturerhebung)). Figures on collective bargaining coverage are not available for the years analysed in this study. We assume that the rank order of collective bargaining strength is stable over the years.

${ }^{29}$ The three sectors with the highest share of R\&D are manufacturing of goods; transport, storage, and communication; and real estate, renting, and business activities. The three sectors with the lowest share of R\&D are hotels and restaurants; public administration, services, and private households; and mining and quarrying (own calculations based on Eurostat Data Base, series business expenditure on R\&D by NACE Rev. 2 the European classification of economic activities).
} 


\begin{tabular}{|c|c|c|c|c|c|c|}
\hline \multirow[b]{3}{*}{ No deductions } & Low & High & Low & High & Low & High \\
\hline & \multicolumn{2}{|c|}{ Employment } & \multicolumn{2}{|c|}{ Unemployment } & \multicolumn{2}{|c|}{ Partial retirement } \\
\hline & Reference & Reference & Reference & Reference & Reference & Reference \\
\hline \multirow[t]{2}{*}{$0.3-3.6$} & $0.125^{* *}$ & $0.139 * *$ & $0.049 * *$ & $0.041^{* *}$ & $0.034^{* *}$ & $0.046 * *$ \\
\hline & $(0.008)$ & $(0.009)$ & $(0.005)$ & $(0.005)$ & $(0.005)$ & $(0.006)$ \\
\hline \multirow[t]{2}{*}{$3.9-7.2$} & $0.151^{* *}$ & $0.154^{* *}$ & $0.066 * *$ & $0.050 * *$ & $0.054^{* *}$ & $0.076^{* *}$ \\
\hline & $(0.010)$ & $(0.010)$ & $(0.007)$ & $(0.006)$ & $(0.006)$ & $(0.007)$ \\
\hline \multirow[t]{2}{*}{$7.5-10.8$} & $0.184^{* *}$ & $0.208^{* *}$ & $0.075^{* *}$ & $0.047^{* *}$ & $0.076 * *$ & $0.106^{* *}$ \\
\hline & $(0.012)$ & $(0.013)$ & $(0.009)$ & $(0.007)$ & $(0.008)$ & $(0.010)$ \\
\hline \multirow[t]{2}{*}{$11.1-14.4$} & $0.220^{* *}$ & $0.259 * *$ & $0.086^{* *}$ & $0.052 * *$ & $0.086 * *$ & $0.132 * *$ \\
\hline & $(0.016)$ & $(0.018)$ & $(0.011)$ & $(0.009)$ & $(0.010)$ & $(0.013)$ \\
\hline \multirow[t]{2}{*}{$14.7-18.0$} & $0.275^{* *}$ & $0.261^{* *}$ & $0.080 * *$ & $0.040 * *$ & $0.091 * *$ & $0.144 * *$ \\
\hline & $(0.026)$ & $(0.026)$ & $(0.018)$ & $(0.014)$ & $(0.015)$ & $(0.019)$ \\
\hline Effect of a 1-year NRA & $1.954^{* *}$ & $2.302^{* *}$ & $0.683^{* *}$ & $0.485^{* *}$ & $0.606^{* *}$ & $0.881^{* *}$ \\
\hline increase in months & $(0.374)$ & $(0.354)$ & $(0.122)$ & $(0.110)$ & $(0.075)$ & $(0.124)$ \\
\hline$N$ & 178,852 & 177,144 & 178,852 & 177,144 & 178,852 & 177,144 \\
\hline Pre-reform mean & 0.094 & 0.108 & 0.011 & 0.007 & 0.0005 & 0.002 \\
\hline $\mathrm{R}^{2}$ & 0.242 & 0.238 & 0.075 & 0.074 & 0.106 & 0.160 \\
\hline
\end{tabular}

Tab. 2. Inflow of older employees. Notes: High is defined as last employer in career with above the $75^{\text {th }}$ percentile of inflow share of employees older than 55 compared with employees younger than 30 , low means that last employer has less than the $25^{\text {th }}$ percentile of inflow share of older employees. We control for SSW with a planning age of 55 , and changes in the legislation for disability pensions and in the entitlement rules for unemployment insurance. Moreover, we consider the job exposure and education, regional unemployment rates, and firm characteristics in our estimation. Standard errors in parentheses are clustered on the individual level. The coefficients marked in bold mean that the firm types are at least significantly different at the $5 \%$ level. The pre-reform mean is calculated for the cohorts 1937 to 1939 . Source: SIAB7514, own calculations. 


\begin{tabular}{|c|c|c|c|c|c|c|}
\hline & $\begin{array}{l}\text { No dismissal } \\
\text { protection }\end{array}$ & $\begin{array}{l}\text { Dismissal } \\
\text { protection }\end{array}$ & $\begin{array}{l}\text { No dismissal } \\
\text { protection }\end{array}$ & $\begin{array}{l}\text { Dismissal } \\
\text { protection }\end{array}$ & $\begin{array}{l}\text { No dismissal } \\
\text { protection }\end{array}$ & $\begin{array}{c}\text { Dismissal } \\
\text { protection }\end{array}$ \\
\hline & \multicolumn{2}{|c|}{ Employment } & \multicolumn{2}{|c|}{ Unemployment } & \multicolumn{2}{|c|}{ Partial retirement } \\
\hline No deductions & Reference & Reference & Reference & Reference & Reference & Reference \\
\hline \multirow[t]{2}{*}{$0.3-3.6$} & $0.088 * *$ & $0.143^{* *}$ & $0.069 * *$ & $0.056 * *$ & 0.019 & $0.020 * *$ \\
\hline & $(0.022)$ & $(0.017)$ & $(0.018)$ & $(0.012)$ & $(0.010)$ & $(0.007)$ \\
\hline \multirow[t]{2}{*}{$3.9-7.2$} & $0.131^{* *}$ & $0.157^{* *}$ & $0.070 * *$ & $0.074^{* *}$ & $0.032 *$ & $0.035 * *$ \\
\hline & $(0.029)$ & $(0.020)$ & $(0.022)$ & $(0.015)$ & $(0.014)$ & $(0.010)$ \\
\hline \multirow[t]{2}{*}{$7.5-10.8$} & $0.166^{* *}$ & $0.174 * *$ & $0.064^{* *}$ & $0.065^{* *}$ & $0.039 * *$ & $0.042 * *$ \\
\hline & $(0.035)$ & $(0.025)$ & $(0.028)$ & $(0.017)$ & $(0.015)$ & $(0.013)$ \\
\hline \multirow[t]{2}{*}{$11.1-14.4$} & $0.209 * *$ & $0.227^{* *}$ & $0.079 * *$ & $0.081^{* *}$ & $0.036 *$ & 0.024 \\
\hline & $(0.046)$ & $(0.033)$ & $(0.040)$ & $(0.022)$ & $(0.018)$ & $(0.014)$ \\
\hline \multirow[t]{2}{*}{$14.7-18.0$} & $0.242^{* *}$ & $0.286 * *$ & 0.070 & $0.096 * *$ & 0.057 & 0.023 \\
\hline & $(0.068)$ & $(0.053)$ & $(0.066)$ & $(0.040)$ & $(0.031)$ & $(0.023)$ \\
\hline Effect of a 1-year & $1.755^{*}$ & $2.343 * *$ & $0.709 *$ & $0.698 * *$ & $0.200 *$ & $0.552 * *$ \\
\hline $\begin{array}{l}\text { NRA increase in } \\
\text { months }\end{array}$ & $(0.739)$ & $(0.434)$ & $(0.291)$ & $(0.150)$ & $(0.083)$ & $(0.089)$ \\
\hline$N$ & 20,929 & 47,215 & 20,929 & 47,215 & 20,929 & 47,215 \\
\hline Pre-reform mean & 0.094 & 0.085 & 0.009 & 0.013 & 0.000 & 0.002 \\
\hline$R^{2}$ & 0.465 & 0.329 & 0.185 & 0.121 & 0.322 & 0.172 \\
\hline
\end{tabular}

Tab. 3. Employers subject or not subject to dismissal protection. Notes: Dismissal protection if the last employer has more than five employees; no dismissal protection if the employer has five or fewer employees. We control for SSW with a planning age of 55, and changes in the legislation for disability pensions and in the entitlement rules for unemployment insurance. Moreover, we consider the job exposure and education, regional unemployment rates, and employer characteristics in our estimation. Standard errors in parentheses are clustered on the individual level. The coefficients marked in bold mean that the firm types are at least significantly different at the $5 \%$ level. The pre-reform mean is calculated for the cohorts 1937 to 1939. Source: SIAB7514, own calculations. 


\begin{tabular}{|c|c|c|c|c|c|c|}
\hline & Low coverage & High coverage & Low coverage & High coverage & Low coverage & High coverage \\
\hline & \multicolumn{2}{|c|}{ Employment } & \multicolumn{2}{|c|}{ Unemployment } & \multicolumn{2}{|c|}{ Partial retirement } \\
\hline No deductions & Reference & Reference & Reference & Reference & Reference & Reference \\
\hline \multirow[t]{2}{*}{$0.3-3.6$} & $0.136^{* *}$ & $0.139 * *$ & $0.062 * *$ & $0.017^{* *}$ & $0.023 * *$ & $0.096 * *$ \\
\hline & $(0.008)$ & (0.009) & $(0.006)$ & $(0.004)$ & $(0.004)$ & $(0.008)$ \\
\hline \multirow[t]{2}{*}{$3.9-7.2$} & $0.169^{* *}$ & $0.153^{* *}$ & $0.077^{* *}$ & $0.022^{* *}$ & $0.036 * *$ & $0.134 * *$ \\
\hline & $(0.009)$ & $(0.012)$ & $(0.008)$ & $(0.005)$ & $(0.005)$ & $(0.010)$ \\
\hline \multirow[t]{2}{*}{$7.5-10.8$} & $0.205^{* *}$ & $0.195^{* *}$ & $0.076 * *$ & $0.020^{* *}$ & $0.046 * *$ & $0.168 * *$ \\
\hline & $(0.012)$ & $(0.015)$ & $(0.009)$ & $(0.005)$ & $(0.006)$ & $(0.012)$ \\
\hline \multirow[t]{2}{*}{$11.1-14.4$} & $0.238^{* *}$ & $0.229 * *$ & $0.097 * *$ & $0.021^{* *}$ & $0.053^{* *}$ & $0.188 * *$ \\
\hline & $(0.016)$ & (0.019) & $(0.013)$ & $(0.006)$ & $(0.008)$ & $(0.015)$ \\
\hline \multirow[t]{2}{*}{$14.7-18.0$} & $0.273 * *$ & $0.234^{* *}$ & $0.061^{* *}$ & $0.033^{* *}$ & $0.057^{* *}$ & $0.212 * *$ \\
\hline & $(0.024)$ & $(0.028)$ & $(0.018)$ & $(0.010)$ & $(0.013)$ & $(0.024)$ \\
\hline Effect of a 1-year NRA & $1.497^{* *}$ & $2.032^{* *}$ & $0.943^{* *}$ & $0.172^{* *}$ & $0.498^{* *}$ & $1.553^{* *}$ \\
\hline increase in months & $(0.371)$ & $(0.424)$ & $(0.117)$ & $(0.061)$ & $(0.069)$ & $(0.139)$ \\
\hline$N$ & 187,575 & 149,389 & 187,575 & 149,389 & 187,575 & 149,389 \\
\hline Pre-reform mean & 0.099 & 0.110 & 0.011 & 0.002 & 0.0004 & 0.001 \\
\hline$R^{2}$ & 0.237 & 0.258 & 0.083 & 0.065 & 0.090 & 0.183 \\
\hline
\end{tabular}




\begin{tabular}{|c|c|c|c|c|c|c|}
\hline & $\begin{array}{l}\text { Low R\&D } \\
\text { expenditure }\end{array}$ & $\begin{array}{l}\text { High R\&D } \\
\text { expenditure }\end{array}$ & $\begin{array}{l}\text { Low R\&D } \\
\text { expenditure }\end{array}$ & $\begin{array}{l}\text { High R\&D } \\
\text { expenditure }\end{array}$ & $\begin{array}{l}\text { Low R\&D } \\
\text { expenditure }\end{array}$ & $\begin{array}{l}\text { High R\&D } \\
\text { expenditure }\end{array}$ \\
\hline & \multicolumn{2}{|c|}{ Employment } & \multicolumn{2}{|c|}{ Unemployment } & \multicolumn{2}{|c|}{ Partial retirement } \\
\hline No deductions & Reference & Reference & Reference & Reference & Reference & Reference \\
\hline \multirow{2}{*}{$0.3-3.6$} & $0.140 * *$ & $0.117^{* *}$ & $0.023^{* *}$ & $0.053 * *$ & $0.070^{* *}$ & $0.036 * *$ \\
\hline & $(0.007)$ & $(0.007)$ & $(0.003)$ & $(0.005)$ & $(0.005)$ & $(0.004)$ \\
\hline \multirow[t]{2}{*}{$3.9-7.2$} & $0.162^{* *}$ & $0.146^{* *}$ & $0.029 * *$ & $0.069 * *$ & $0.104^{* *}$ & $0.061 * *$ \\
\hline & $(0.008)$ & $(0.008)$ & $(0.004)$ & $(0.007)$ & $(0.006)$ & $(0.006)$ \\
\hline \multirow[t]{2}{*}{$7.5-10.8$} & $0.202^{* *}$ & $0.197^{* *}$ & $0.031^{* *}$ & $0.076 * *$ & $0.139 * *$ & $0.080 * *$ \\
\hline & $(0.01)$ & $(0.011)$ & $(0.004)$ & $(0.008)$ & $(0.008)$ & $(0.007)$ \\
\hline \multirow[t]{2}{*}{$11.1-14.4$} & $0.240 * *$ & $0.226 * *$ & $0.031 * *$ & $0.088^{* *}$ & $0.159 * *$ & $0.093 * *$ \\
\hline & $(0.013)$ & $(0.014)$ & $(0.005)$ & $(0.010)$ & $(0.010)$ & $(0.009)$ \\
\hline \multirow[t]{2}{*}{$14.7-18.0$} & $0.250 * *$ & $0.257^{* *}$ & $0.039 * *$ & $0.086 * *$ & $0.179 * *$ & $0.104 * *$ \\
\hline & $(0.019)$ & $(0.021)$ & $(0.009)$ & $(0.016)$ & $(0.015)$ & $(0.015)$ \\
\hline \multirow{2}{*}{$\begin{array}{l}\text { Effect of a 1-year NRA increase in } \\
\text { months }\end{array}$} & $2.033^{* *}$ & $1.921^{* *}$ & $0.299 * *$ & 0.754 & $1.193^{* *}$ & $0.536^{* *}$ \\
\hline & $(0.298)$ & $(0.293)$ & $(0.063)$ & $(0.116)$ & $(0.092)$ & $(0.090)$ \\
\hline$N$ & 316,956 & 248,636 & 316,956 & 248,636 & 316,956 & 248,636 \\
\hline Pre-reform mean & 0.118 & 0.071 & 0.006 & 0.019 & 0.001 & 0.002 \\
\hline$R^{2}$ & 0.239 & 0.211 & 0.044 & 0.071 & 0.143 & 0.097 \\
\hline
\end{tabular}

"is defined as last employer is in the three economic sectors of the economy with the highest R\&D expenses in 2003. "low" is defined as last employer is in the three sectors with the lowest R\&D expenses in 2003. We control for SSW with a planning age of 55, and changes in the legislation for disability pensions and in the entitlement rules for unemployment insurance. Moreover, we consider the job exposure and education, regional unemployment rates, and firm characteristics in our estimation. Standard errors in parentheses are clustered on the individual level. The coefficients marked in bold mean that the firm types are at least significantly different at the $5 \%$ level. The pre-reform mean is calculated for the cohorts 1937 to 1939 . Source: SIAB7514, own calculations. 


\section{Conclusions}

Labor demand and supply for older employees are not perfectly flexible, and thus the reaction of both market sides to labor supply shocks induced by policy measures should have an impact on labor market outcomes. Pension reforms have been a regular trigger of labor supply shocks of clearly defined subgroups of the labor force in most developed countries since the 1990s. Nevertheless, the empirical literature on the effects of pension reforms on individual labor market outcomes has focused mainly on the labor supply reaction. Thus, this literature assumed autonomy in the reaction of older employees on when and how to leave the labor market and a perfectly elastic labor demand reaction of their employers.

We concentrate on the role of labor demand for the labor market effects of the 1992 pension reform in Germany, controlling for drivers of individual labor supply reactions, such as differences in financial incentives by birth cohort, SSW, and education, as well as age and cohort fixed effects. We also include labor demand reactions, controlling for many labor demand characteristics, such as workforce characteristics and regional unemployment, as well as establishment fixed effects. The 1992 pension reform introduced yearly deductions of $3.6 \%$ on pension entitlements for women in the case of retirement before the NRA and a stepwise increase in the NRA from 60 to 65 years, keeping the ERA constant at age 60. We show that the reform had the expected effects on the labor market behavior of affected older women; they strongly increased employment and, to a lesser extent, unemployment and partial retirement between the ERA and NRA to avoid pension deductions. Our results on the employment and unemployment effects for our sample for women who were all eligible for early retirement and close to the labor market before retirement are comparable to previous results (Engels et al., 2017). For the first time, we calculate the effects of the pension reform on partial retirement after the ERA, an additional early retirement bridge introduced with the pension reform.

Based on labor demand theory, we derive hypotheses on which groups of employers should be more responsive to the interests of employees to stay longer in employment or partial retirement after ERA. Less responsive employers block longer employment, dismiss older employees before ERA, and thereby induce longer unemployment spells after ERA. According to these hypotheses, we show that employers with a high share of older employees compared with the share of young employees hired, employers in sectors with a high share of collective bargaining agreements, employers in sectors with few investments in R\&D are more responsive. Dismissal protection does not appear to play an important role in employer behavior. We also show that the labor demand impact is stronger for partial retirement and unemployment than for regular employment. Older women eligible for the pension for women have the statutory right to determine the date of their early retirement exit from employment, 
and thus they can unilaterally prolong their employment spell after the ERA. The difference among employer groups is substantial. For example, if the NRA increases by 1 year, employees in sectors with high collective bargaining coverage stay more than one month longer in partial retirement after the ERA than employees in sectors with low collective bargaining coverage. The analogous difference is 0.2 months in unemployment incidence after the ERA in firms with a high share of new hires older than 55 compared with hires younger than 30 . Women working in sectors with high R\&D expenditure show longer unemployment spells after the ERA and shorter part-time work spells after the ERA than women working in sectors with low R\&D expenditure.

Our paper therefore shows that old employees are not autonomous in deciding when and how to leave the labor market and employers do not perfectly elastically react to labor supply shocks. In order to understand the treatment effects of pension reforms on labor market outcomes of older employees, we must consider the labor demand reactions of their employers. Employers with higher adaption costs use their options not to prolong the employment spell of their employees after the ERA, even if this induces longer unemployment and other financial disadvantages for their employees. Therefore, it makes a difference for a given employee affected by a pension reform whether she works for an employer that is subject to collective bargaining, invests heavily in R\&D, or is interested in rejuvenating the workforce when hiring new staff.

We used a large administrative labor market history data set covering a representative sample of all employees in Germany. The data set allows us to control for the relevant individual financial retirement incentives. However, the establishment information in the data set is limited. Therefore, it would be interesting to analyze the labor supply influence of the presence of a works council or collective bargaining coverage directly instead of using the sector proxy. In addition, the influence of the pension reform on other labor market outcomes, such as the earnings of older employees, substitution of younger by older employees, or employment after retirement, are interesting topics for future research. Finally, it would be desirable to extend the analysis and to model general equilibrium effects of the policy reform. 


\section{References}

Antoni, M., A. Ganzer, and P. vom Berge (2016): "Stichprobe der Integrierten Arbeitsmarktbiografien (SIAB) 1975-2014", FDZ Datenreport, 04/2016.

Atalay, K. and G. F. Barrett (2015): "The impact of age pension eligibility age on retirement and program dependence: Evidence from an Australian experiment", Review of Economics and Statistics, 97(1), 71-87.

Aubert, P. and B. Crépon (2003): "La productivité des salariés âgés: une tentative d'estimation", Économie et statistique, 368, 85-119.

Backes-Gellner, U. and S. Veen (2013): "Positive Effects of Ageing and Age Diversity in Innovative Companies - Large-scale Empirical Evidence on Company Productivity", Human Resource Management Journal, 23(3), 279-295.

Bellmann, L. and F. Janik (2007): "Firms and Early Retirement: Offers That One Does Not Refuse", IZA Discussion Papers, 2931, Bonn.

Bello, P. and V. Galasso (2015): "Old before Their Time: The Role of Employers in Retirement Decisions", CEPR Discussion Papers, 11007.

Berg, P., M. Hamman, M. Piszczek, and C. Ruhm (2015): “Can Policy Facilitate Partial Retirement? Evidence from Germany", NBER Working Paper, 21478, Cambridge MA.

Berkel, B. and A. Börsch-Supan (2004): "Pension reform in Germany: The impact on retirement decisions", FinanzArchiv: Public Finance Analysis, 60(3), 393-421.

Boeri, T., P. Garibaldi, and E. Moen (2016): "A Clash of Generations? Increase in Retirement Age and Labor Demand for Youth", Centre for Economic Policy Research Discussion Paper, 11422.

Börsch-Supan, A. and C. Coile (2018): "Social security programs and retirement around the world: Reforms and retirement incentives - introduction and summary", NBER Working Paper series, 25280.

Börsch-Supan, A., R. Schnabel, S. Kohn, and G. Mastrobuoni (2004): "Micro-Modeling of Retirement Decisions in Germany", in: J. Gruber, and D. A. Wise (ed.), Social Security Programs and Retirement around the World: Micro-Estimation, Chicago: University of Chicago Press, 285-343.

Bovini, G. and M. Paradisi (2017): “The Transitional Labor Market Consequences of a Pension Reform", Mimeo.

Brinch, C. N., O. L. Vestad, and J. Zweimüller (2015): "Excess early retirement? Evidence from the Norwegian 2011 pension reform", Mimeo.

Brussig, M., M. Knuth, and S. Wojtkowski (2009): "Altersteilzeit: Zunehmend Beschäftigungsbrücke zum späteren Renteneintritt. Wegfall der Förderung verengt auch den Zugang in nichtgeförderte Altersteilzeit-Nachfolgetarifverträge fehlen", Altersübergangs-Report, 2009-2.

Bruttel, O., A. Baumann, and M. Dütsch (2018): "The new German statutory minimum wage in comparative perspective: Employment effects and other adjustment channels", European Journal of Industrial Relations, 24(2), 145-162.

Bundesagentur für Arbeit (2015): "Altersteilzeitgesetz. Durchführungsanweisungen. 7. Ergänzung zur Neuauflage", Nuremberg.

Bundesagentur für Arbeit (2019): “Arbeitslosigkeit im Zeitverlauf: Entwicklung der Arbeitslosenquote”, Nuremberg.

Caliendo, M., C. Schröder, and L. Wittbrodt (2019): "The Causal Effects of the Minimum Wage Introduction in Germany - An Overview", German Economic Review, 20(3), 257-92.

Card, D. and A. Krueger (1994): "Minimum Wages and Employment: A Case Study of the Fast-Food Industry in New Jersey and Pennsylvania", American Economic Review, 84(4), 772-793. 
Coe, N. B. and K. Haverstick (2010): "Measuring the Spillover to Disability Insurance Due to the Rise in the Full Retirement Age", Boston College Center for Retirement Research Working Paper, 2010-21.

Deutsche Rentenversicherung Bund (2018): "Rentenversicherung in Zahlen 2018", Berlin.

Duggan, M., P. Singleton, and J. Song (2007): "Aching to retire? The rise in the full retirement age and its impact on the social security disability rolls", Journal of Public Economics, 91(7), 1327-1350.

Dustmann, C., U. Schönberg, and J. Stuhler (2017): "Labor Supply Shocks, Native Wages, and the Adjustment of Local Employment", Quarterly Journal of Economics, 132(1), 435-483.

Engels, B., J. Geyer, and P. Haan (2017): "Pension incentives and early retirement", Labour Economics, 47, 216-231.

Gibbons, R. and M. Waldman (2006): "Enriching a Theory of Wage and Promotion Dynamics Inside Firms", Journal of Labor Economics, 24(1), 59-108.

Hakola, T. and R. Uusitalo (2005): "Not so voluntary retirement decisions? Evidence from a pension reform", Journal of Public Economics, 89(11), 2121-36.

Hallberg, D. (2011): "Is Early Retirement Encouraged by the Employer? Labor-Demand Effects of AgeRelated Collective Fees", 2011:5. Working Paper Series, Center for Labor Studies. Uppsala University, Department of Economics.

Hanappi, T. (2012): "Retirement Behaviour in Austria: Incentive Effects on Old-Age Labor Supply", NRN Working Paper, 1213.

Hanel, B. (2010): "Financial incentives to postpone retirement and further effects on employment Evidence from a natural experiment", Labour Economics, 17(3), 474-486.

Hanel, B. and R. Riphahn (2012): "The timing of retirement: New evidence from Swiss female workers", Labour Economics, 19(5), 718-728.

Hellerstein J., D. Neumark, and K. Troske (1999): "Wages, productivity and worker characteristics: Evidence from plant-level production functions and wage equations", Journal of Labor Economics, 17(3), 409-446.

Hernæs, E., S. Markussen, J. Piggott, and K. Røed (2016): "Pension reform and labor supply", Journal of Public Economics, 142, 39-55.

Hetschko, C., A. Knabe, and R. Schöb (2014): "Changing Identity: Retiring From Unemployment", The Economic Journal, 124(575), 149-66.

Huber, M., M. Lechner, and C. Wunsch (2016): "The Effects of Firms' Phased Retirement Policies on the Labor Market Outcomes of Their Employees", ILR Review, 69(5), 1216-1248.

Ilmakunnas, P. and M. Maliranta (2007): “Aging, Labor Turnover and Firm Performance", Helsinki Center of Economic Research Discussion Paper, 164, Helsinki.

Jahn, E. (2009): "Do Firms Obey the Law When they Fire Workers? Social Criteria and Severance Payments in Germany", International Journal of Manpower, 30(7), 672-691.

Kaldybajewa, K. and E. Kruse (2007): "Altersteilzeit immer beliebter - Statistische Fakten, Interpretationen und Bewertungen“, RVaktuell 8/2007, 244-252.

Kirchner, J. and E. Mittelhamm (2010): "Employee or freelance worker", in: Kirchner, J., P. Kremp, and M. Magotsch (eds.): "Key Aspects of German Employment and Labour Law", Springer, Berlin, Heidelberg, 37-43.

Klammer, U. and H. Weber (2001): "Flexibel in den Ruhestand? - Ergebnisse und Überlegungen zur Altersteilzeit", WSI-Mitteilungen 2/2001, 102-112.

Kondo, A. (2016): "Effects of increased elderly employment on other workers' employment and elderly's earnings in Japan", IZA Journal of Labor Policy, 5(2), 1-23. 
Kroll, L. E. (2011): „Konstruktion und Validierung eines allgemeinen Index für die Arbeitsbelastung in beruflichen Tätigkeiten auf Basis von ISCO-88 und KIdB-92“, Methoden, Daten, Analysen (mda), 5(1), 63-90.

Krueger, A. B. and J.-S. Pischke (1992): "The effect of social security on labor supply: A cohort analysis of the Notch generation", Journal of Labor Economics, 10(4), 412-37.

Lalive, R. and S. Staubli (2015): “How does raising women's full retirement age affect labor supply, income, and mortality?", NBER Retirement Research Center Paper, 14-09.

Lorenz, S., M. Pfister, and T. Zwick (2018): "Identification of the statutory retirement dates in the Sample of Integrated Labor Market Biographies (SIAB)", FDZ Methodenreport, 08/2018.

Manoli, D. S. and A. Weber (2016): "The effects of the early retirement age on retirement decisions", NBER Working Paper, 22561.

Martins, P., A. Novo, and P. Portugal (2009): "Increasing the Legal Retirement Age: The Impact on Wages, Worker Flows and Firm Performance", IZA Discussion Paper, 4187.

Mastrobuoni, G. (2009): "Labor supply effects of the recent social security benefit cuts: Empirical estimates using cohort discontinuities", Journal of Public Economics, 93(11), 1224-1233.

Oswald, C. (1999): “Altersteilzeit: Nur 'Frühpensionierung mit Vorlaufzeit?' Eine Zwischenbilanz", Zeitschrift für Sozialreform, 45(3), 199-221.

Peichl, A. and S. Siegloch (2012): "Accounting for labor demand effects in structural labor supply models", Labour Economics, 19(1), 129-138.

Pfister, M., S. Lorenz, and T. Zwick (2018): "Implementation of Pension Entitlements in the Sample of Integrated Labor Market Biographies (SIAB)", FDZ Methodenreport, 01/2018.

Rabaté, S. (2017): "Can I Stay or Should I Go? Mandatory Retirement and Labor Force Participation of Older Workers", Paris School of Economics Working Papers, 2017-19, Paris.

Riphahn, R. and R. Schrader (2019): "Labor Market Effects of Early Retirement Reforms", Mimeo.

Schmähl, W. (2003): "Ageing Workforce: Firm Strategies and Public Policy in Germany", Geneva Papers on Risk and Insurance - Issues and Practice, 28(4), 575-595.

Schneider, L. (2008): „Alterung und technologisches Innovationspotential - eine linked-employeremployee Analyse", Zeitschrift für Bevölkerungswissenschaft, 33(1), 37-54.

Schubert, T. and M. Andersson (2015): "Old is Gold? The Effects of Employee Age on Innovation and the Moderating Effects of Employment Turnover", Economics of Innovation and New Technology, 24(1-2), 95-113.

Simonton, D. (2007): “Creativity”, in: J. Birren (ed.), The Encyclopedia of Gerontology, San Diego CA: Academic Press, 314-351.

Staubli, S. and J. Zweimüller (2013): "Does raising the early retirement age increase employment of older workers?", Journal of Public Economics, 108(C), 17-32.

Stock, J. and D. A. Wise (1990): "Pension, the Option Value of Work, and Retirement", Econometrica, 58(5), 1151-1180.

Vestad, O. L. (2013): "Labor supply effects of early retirement provision", Labour Economics, 25, 98109.

Vigtel, T. (2018): "The retirement age and the hiring of senior workers", Labour Economics, 51, 247270.

Wanger, S. (2009): „Altersteilzeit: Beliebt, aber nicht zukunftsgerecht“, IAB-Kurzbericht, 08/2009. 


\section{Appendix A: Calculation of social security wealth}

An important driver of employment decisions in old age identified in structural models, explaining, for example, the retirement decision, are individual financial incentives. In their seminal article, Stock and Wise (1990) proposed an empirical method to identify individual financial incentives to retire at a certain age. Their model combines features of the social security system and individual attributes that may simultaneously affect retirement decisions. They identify the financial gains or losses from continuing work before retirement as an incentive measure. Their model focuses on the expected net present discounted value of future social security benefits, social security wealth (SSW).

According to Stock and Wise (1990) and Hanappi (2012) we define SSW as

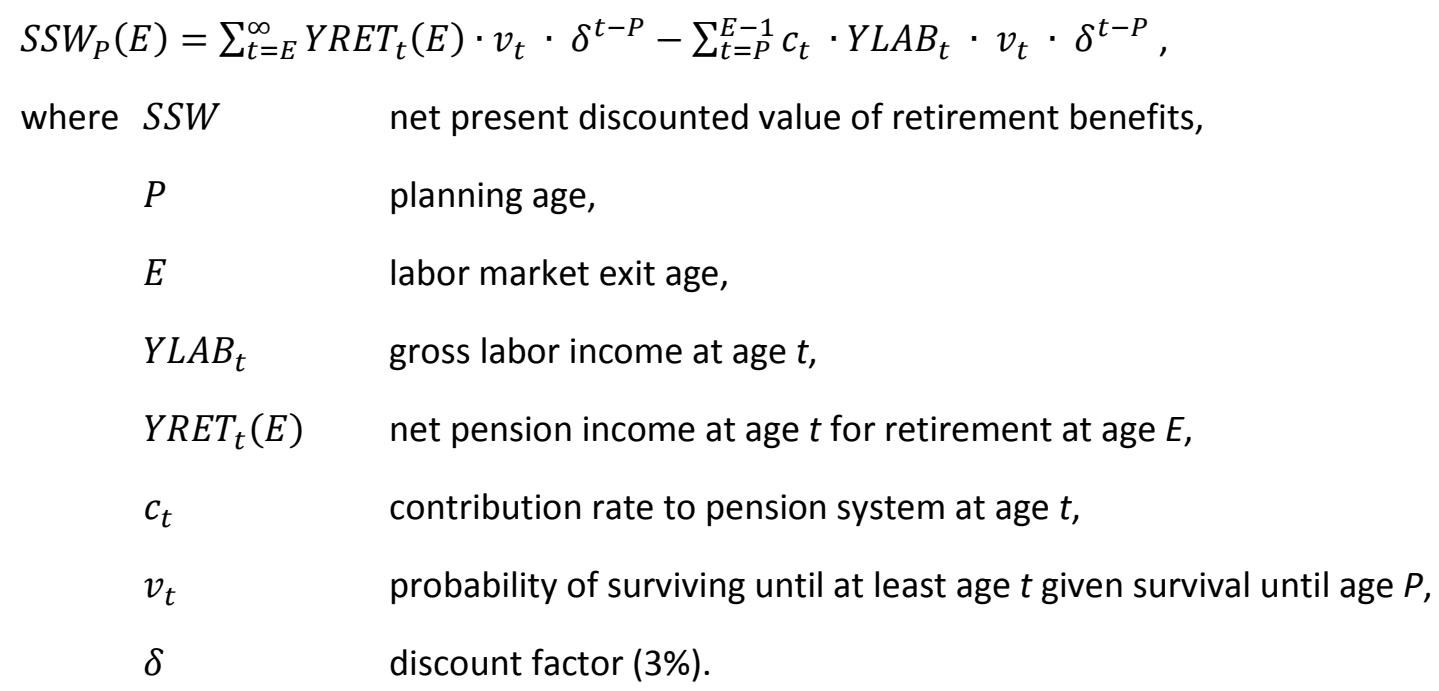

We calculate the SSW for each individual and for each age on a monthly basis. We set the planning age, $P$, at 55 years and 1 month. Individuals theoretically consider whether it is most profitable for them to leave the labor market at 55 years and 2 months, 55 years and 3 months, etc. until 65 years and 1 month $(E)$. The maximum age, $t$, is set to 100 years. We receive the gross labor income from the observed income information if the person has an income. The net pension income is calculated by multiplying the sum of the earning points by the individual age factor and the annual pension value (Pfister et al., 2018). The information on pension value, contribution rate per year, and survival probabilities is imported from the German pension insurance and the standard life tables of the German Bureau of the Census (Statistisches Bundesamt). For the standard life tables, we distinguish according to gender, cohort, and age. We choose the usual annual discount rate of $3 \%(0.25 \%$ per month) (Hanappi, 2012; Börsch-Supan et al., 2004; Hanel, 2010). 
SSW is typically used as a substitute for total wealth in the analysis of pension decisions. Thus, the SSW level shows the expected future earnings, which integrate the individually applicable institutional features of the social security system.

In our framework, leaving the labor market at any later date $E$ instead of any earlier date $E$ - 1 has three effects: (1) social security contributions must be paid for one more period between $E$ - 1 and $E$; (2) the period of total benefit receipt is shortened and changed; and (3) the expected present value of future benefits is increased due to the additional social security payment (i.e., higher pension entitlements) over the entire remaining lifetime, according to the pension formula. Effects (1) and (2) reduce wealth, and hence increase the incentive to leave the labor market immediately. Effect (3) increases the incentive to stay 1 year longer in employment. Consequently, labor market exit at date $E$ instead of $E$ - 1 is preferred only if the increase in the annual pension due to postponement of leaving the labor market is high enough to offset the shorter time of the pension receipt, and to compensate for the additional deposit.

According to Stock and Wise (1990), we assume that leisure is seen as a normal good and that people want more of it when they can afford it. That is, we expect people with a higher SSW to have a higher probability of exiting the labor market than people of the same age with a lower SSW.

Instead of looking at the change in SSW over age, such as the SSW accrual rate, and thus at the increase or decrease in the probability of an individual leaving the labor market, we aggregate the SSW to age 59. There are two reasons for this. The first reason lies in the inclusion of the deductions in the formula of the SSW. The individual net pension incomes are determined by the age factor, which represents the individual deductions. These are calculated from the difference between labor market exit $E$ and the individual NRA. Second, we want to use the SSW as a substitute for individual wealth at a given time. Because the earliest possible age for receiving a pension in our sample is 60 years, we choose the SSW at the age of 59. The wealth effect on retirement is documented in Berkel and Börsch-Supan (2004), Börsch-Supan et al. (2004), Börsch-Supan and Coile (2018), Hanappi (2012), and Hanel (2010). 


\section{Appendix B: Descriptive statistics of individual and employer characteristics}

\begin{tabular}{|c|c|c|c|}
\hline Variable & Mean & SD & $N$ \\
\hline \multicolumn{4}{|l|}{ Employer characteristics by last employment } \\
\hline Total number of employees & 702.889 & 2486.755 & $1,523,269$ \\
\hline Imputed gross daily earnings of full-time employees & 90.191 & 31.962 & $1,523,269$ \\
\hline Employee age & 42.503 & 5.324 & $1,523,269$ \\
\hline Age full-time employees & 42.047 & 5.672 & $1,523,269$ \\
\hline Share women employees & 0.603 & 0.255 & $1,523,269$ \\
\hline Share full-time employees & 0.623 & 0.248 & $1,523,269$ \\
\hline Share part-time employees & 0.210 & 0.196 & $1,523,269$ \\
\hline Share regular employees & 0.829 & 0.190 & $1,523,269$ \\
\hline Share apprentices & 0.037 & 0.060 & $1,523,269$ \\
\hline Share women full-time employees & 0.296 & 0.196 & $1,523,269$ \\
\hline Share women part-time employees & 0.191 & 0.184 & $1,523,269$ \\
\hline Share regular full-time employees & 0.621 & 0.248 & $1,523,269$ \\
\hline Share low-skilled employees & 0.156 & 0.137 & $1,523,269$ \\
\hline Share medium-skilled employees & 0.717 & 0.181 & $1,523,269$ \\
\hline Share high-skilled employees & 0.113 & 0.155 & $1,523,269$ \\
\hline
\end{tabular}




\begin{tabular}{|c|c|c|c|}
\hline Variable & Mean & SD & $N$ \\
\hline Share low-skilled full-time employees & 0.064 & 0.103 & $1,523,269$ \\
\hline Share medium-skilled full-time employees & 0.472 & 0.219 & $1,523,269$ \\
\hline Share high-skilled full-time employees & 0.082 & 0.118 & $1,523,269$ \\
\hline Share employees $55-59$ years old & 0.120 & 0.121 & $1,523,269$ \\
\hline Share employees $60-64$ years old & 0.063 & 0.100 & $1,523,269$ \\
\hline Regional unemployment rate & 10.001 & 3.596 & $1,523,269$ \\
\hline \multicolumn{4}{|l|}{ Individual characteristics } \\
\hline Job exposure index: Overall Job Index & 4.918 & 3.083 & $1,523,269$ \\
\hline Job exposure index: Overall Physical Exposure Index & 4.679 & 2.958 & $1,523,269$ \\
\hline Job exposure index: Overall Psycho-social Exposure Index & 5.153 & 3.182 & $1,523,269$ \\
\hline Job exposure index: Carcinogenic Agent Index & 4.655 & 2.890 & $1,523,269$ \\
\hline Job exposure index: Heavy Work Index & 4.920 & 2.982 & $1,523,269$ \\
\hline SSW at age 55 & $186,211.6$ & $54,065.14$ & $1,523,269$ \\
\hline
\end{tabular}




\section{Appendix C:}

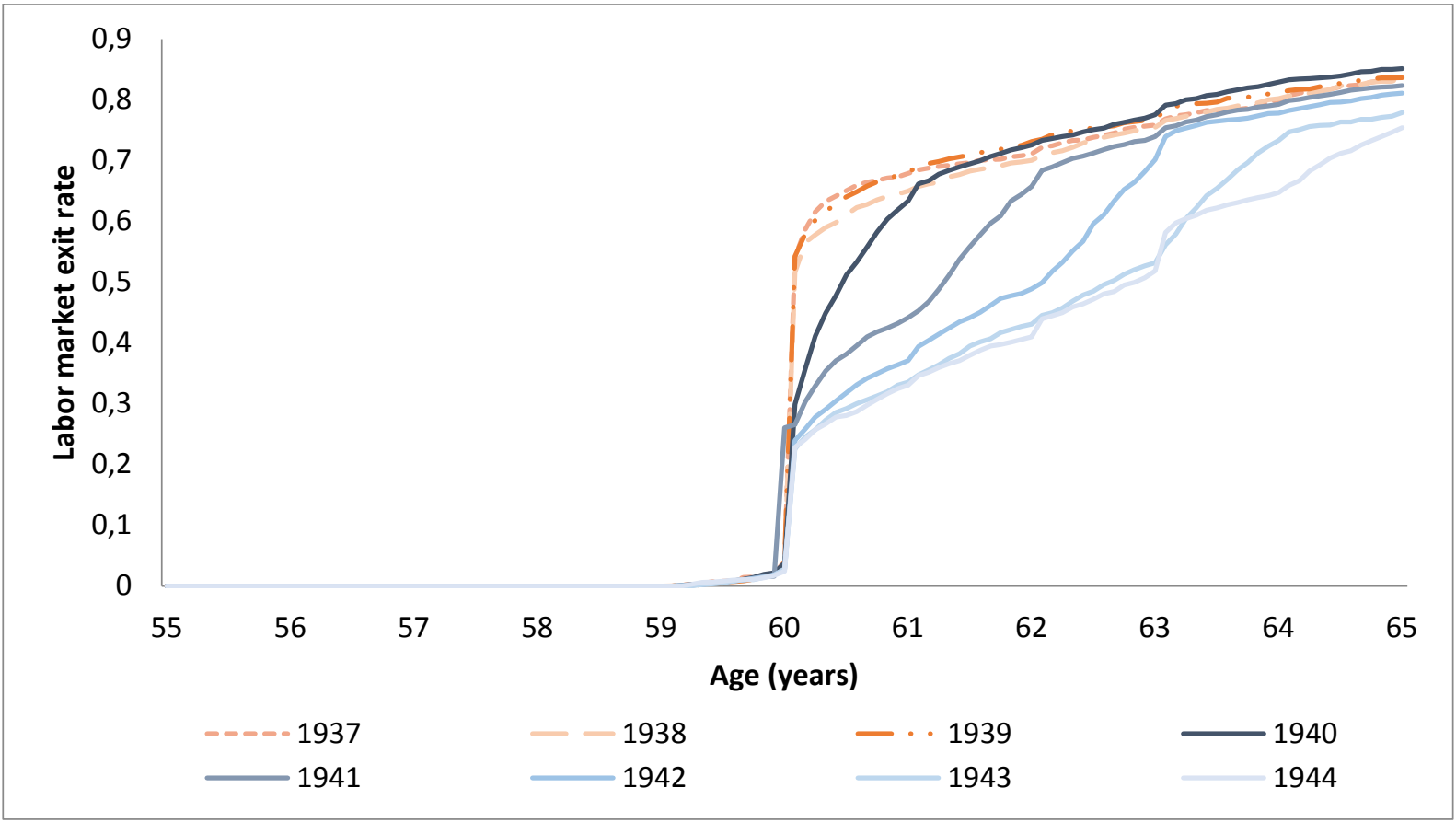

Fig. C1. Labor market exit rates by age (monthly data) and cohort. Source: SIAB7514, own calculations.

As our sample only includes women who have completed their last employment after the age of 59, we do not observe labor market exit before age 59.

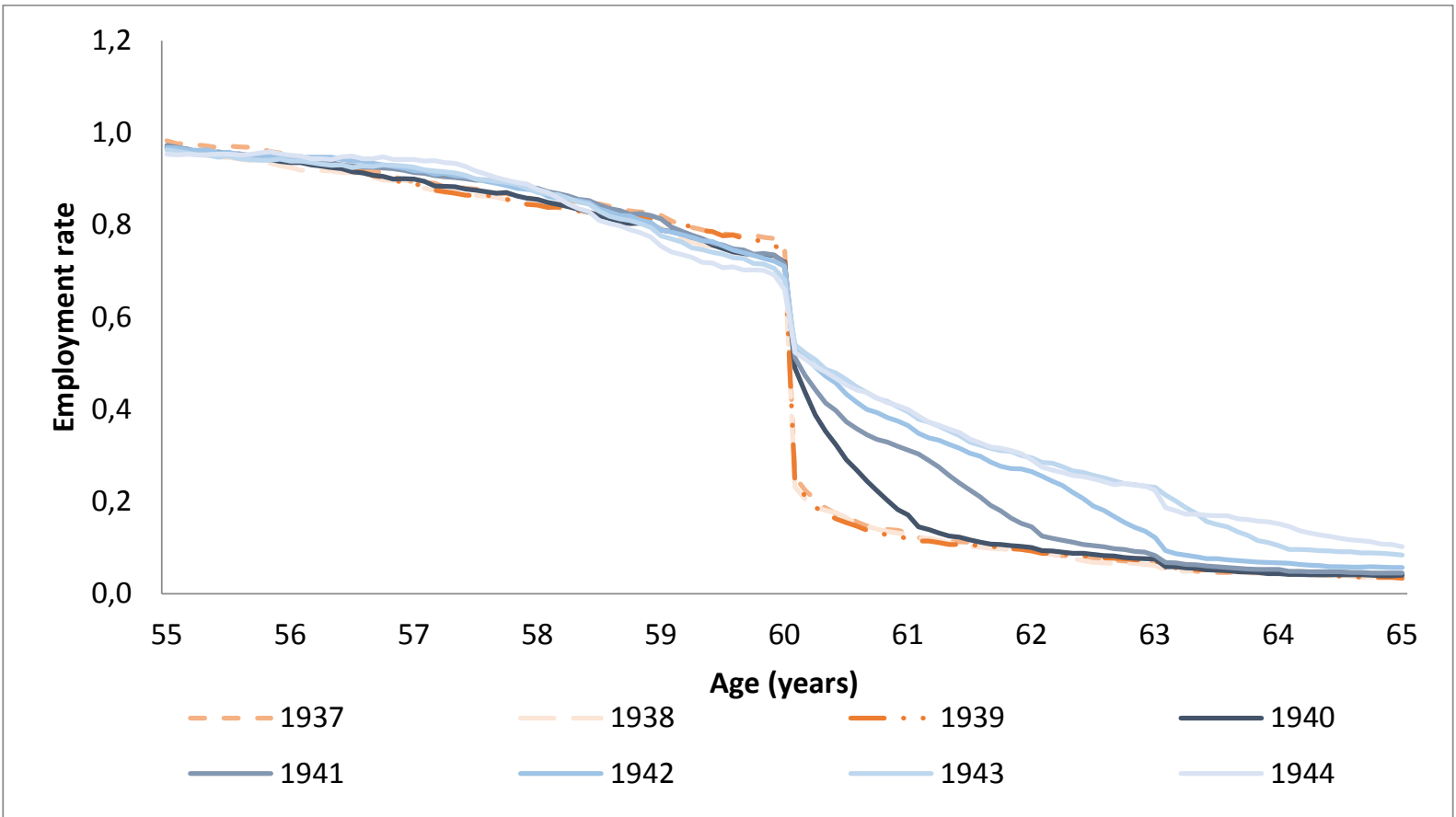

Fig. C2. Employment rates (employment subject to social security contributions with active phase of partial retirement) by age (monthly data) and cohort. Source: SIAB7514, own calculations. 
Appendix D:

\begin{tabular}{|c|c|c|c|}
\hline & Employment & $\begin{array}{c}\text { Partial } \\
\text { retirement }\end{array}$ & Unemployment \\
\hline No deductions & Reference & Reference & Reference \\
\hline \multirow[t]{2}{*}{$0.3-3.6$} & 0.127 & $0.046 * *$ & $0.042 * *$ \\
\hline & $(0.004)$ & $(0.003)$ & $(0.002)$ \\
\hline \multirow[t]{2}{*}{$3.9-7.2$} & $0.152^{* *}$ & $0.073 * *$ & $0.055^{* *}$ \\
\hline & $(0.005)$ & $(0.003)$ & $(0.003)$ \\
\hline \multirow[t]{2}{*}{$7.5-10.8$} & $0.192 * *$ & $0.100 * *$ & $0.058 * *$ \\
\hline & $(0.006)$ & $(0.004)$ & $(0.004)$ \\
\hline \multirow[t]{2}{*}{$11.1-14.4$} & $0.225^{* *}$ & $0.118^{* *}$ & $0.064^{* *}$ \\
\hline & $(0.008)$ & $(0.006)$ & $(0.005)$ \\
\hline \multirow[t]{2}{*}{ 14.7-18.0 } & $0.251 * *$ & $0.131 * *$ & $0.058 * *$ \\
\hline & $(0.012)$ & $(0.009)$ & $(0.007)$ \\
\hline \multirow[t]{2}{*}{ SSW } & $-0.05^{* *}$ & $0.01 * *$ & $-0.007 * *$ \\
\hline & $(0.005)$ & $(0.003)$ & $(0.002)$ \\
\hline \multirow[t]{2}{*}{ Overall Job Index } & 0.011 & 0.006 & -0.001 \\
\hline & $(0.008)$ & $(0.004)$ & $(0.003)$ \\
\hline \multirow[t]{2}{*}{ Overall Physical Exposure Index } & -0.010 & -0.006 & 0.001 \\
\hline & $(0.007)$ & $(0.003)$ & $(0.003)$ \\
\hline \multirow[t]{2}{*}{ Overall Psycho-social Exposure Index } & 0.004 & -0.003 & -0.0006 \\
\hline & $(0.003)$ & $(0.002)$ & $(0.001)$ \\
\hline \multirow[t]{2}{*}{ Carcinogenic Agent Index } & -0.001 & 0.0007 & -0.0001 \\
\hline & $(0.003)$ & $(0.001)$ & $(0.0010)$ \\
\hline \multirow[t]{2}{*}{ Heavy Work Index } & $-0.009 * *$ & 0.002 & 0.0009 \\
\hline & $(0.002)$ & $(0.001)$ & $(0.0009)$ \\
\hline \multirow[t]{2}{*}{ Total number of employees } & $-4.05 e-06 * *$ & $-4.65 e-08 * *$ & $-1.07 e-06 * *$ \\
\hline & (8.12e-07) & (4.71e-07) & $(2.19 \mathrm{e}-07)$ \\
\hline \multirow{3}{*}{$\begin{array}{l}\text { Imputed gross daily earnings of full-time } \\
\text { employees }\end{array}$} & & & \\
\hline & $0.001^{* *}$ & $0.0006 * * * *$ & $-0.0003 * * *$ \\
\hline & $(0.0001)$ & $(0.00007)$ & $(0.00005)$ \\
\hline \multirow[t]{2}{*}{ Employee age } & $0.008 * *$ & $0.002 * *$ & -0.0009 \\
\hline & $(0.001)$ & $(0.0005)$ & $(0.0005)$ \\
\hline \multirow[t]{2}{*}{ Age full-time employees } & $0.004 * *$ & $-0.002 * *$ & 0.0005 \\
\hline & $(0.0009)$ & $(0.0003)$ & $(0.0004)$ \\
\hline \multirow[t]{2}{*}{ Share women employees } & $-0.314^{* *}$ & $-0.086 * *$ & $0.053 *$ \\
\hline & $(0.063)$ & $(0.026)$ & $(0.023)$ \\
\hline \multirow[t]{2}{*}{ Share full-time employees } & 0.403 & -0.086 & 0.105 \\
\hline & $(0.207)$ & $(0.058)$ & $(0.078)$ \\
\hline \multirow[t]{2}{*}{ Share part-time employees } & 0.130 & -0.077 & 0.017 \\
\hline & $(0.126)$ & $(0.051)$ & $(0.038)$ \\
\hline \multirow[t]{2}{*}{ Share regular employees } & $-0.594 * *$ & -0.018 & $0.057^{*}$ \\
\hline & $(0.101)$ & $(0.038)$ & $(0.028)$ \\
\hline Share apprentices & $\begin{array}{l}-0.049 \\
(0.058)\end{array}$ & $\begin{array}{c}0.031 \\
(0.022)\end{array}$ & $\begin{array}{l}-0.006 \\
(0.021)\end{array}$ \\
\hline
\end{tabular}




\begin{tabular}{|c|c|c|c|}
\hline & Employment & $\begin{array}{c}\text { Partial } \\
\text { retirement }\end{array}$ & Unemployment \\
\hline \multirow[t]{2}{*}{ Share women full-time employees } & $0.388 * *$ & $0.081^{* *}$ & $-0.063^{*}$ \\
\hline & $(0.067)$ & $(0.027)$ & $(0.025)$ \\
\hline \multirow[t]{2}{*}{ Share women part-time employees } & $0.206^{*}$ & 0.074 & -0.075 \\
\hline & (0.099) & $(0.043)$ & (0.039) \\
\hline \multirow[t]{2}{*}{ Share regular full-time employees } & $-0.076 * *$ & $0.124 *$ & -0.085 \\
\hline & $(0.197)$ & $(0.053)$ & $(0.064)$ \\
\hline \multirow[t]{2}{*}{ Share low-skilled employees } & 0.093 & $0.134 * *$ & 0.00009 \\
\hline & $(0.091)$ & $(0.028)$ & $(0.037)$ \\
\hline \multirow[t]{2}{*}{ Share medium-skilled employees } & $0.184 *$ & $0.163 * *$ & 0.005 \\
\hline & $(0.087)$ & $(0.026)$ & $(0.035)$ \\
\hline \multirow[t]{2}{*}{ Share high-skilled employees } & $0.295^{* *}$ & $0.209 * *$ & -0.027 \\
\hline & $(0.097)$ & $(0.035)$ & $(0.037)$ \\
\hline \multirow[t]{2}{*}{ Share low-skilled full-time employees } & -0.222 & -0.075 & 0.0006 \\
\hline & $(0.120)$ & $(0.041)$ & $(0.056)$ \\
\hline \multirow[t]{2}{*}{ Share medium-skilled full-time employees } & $-0.304 * *$ & $-0.136 * *$ & 0.009 \\
\hline & $(0.115)$ & (0.039) & $(0.052)$ \\
\hline \multirow[t]{2}{*}{ Share high-skilled full-time employees } & $-0.426 * *$ & $-0.215^{* *}$ & 0.054 \\
\hline & (0.129) & $(0.050)$ & $(0.056)$ \\
\hline \multirow[t]{2}{*}{ Share employees $55-59$ years old } & $-0.419 * *$ & -0.005 & $0.045^{* *}$ \\
\hline & $(0.026)$ & $(0.010)$ & $(0.013)$ \\
\hline \multirow[t]{2}{*}{ Share employees $60-64$ years old } & $0.093^{*}$ & -0.005 & 0.020 \\
\hline & $(0.040)$ & $(0.010)$ & $(0.017)$ \\
\hline \multirow[t]{2}{*}{ Regional unemployment rate } & $-0.002 * *$ & 0.0002 & $0.0007^{* *}$ \\
\hline & $(0.0006)$ & $(0.0003)$ & $(0.0002)$ \\
\hline $\mathrm{N}$ & 765,428 & 765,428 & 765,428 \\
\hline Pre-reform mean & 0.097 & 0.001 & 0.011 \\
\hline $\mathrm{R}^{2}$ & 0.219 & 0.113 & 0.062 \\
\hline
\end{tabular}

Tab. D1. Direct effects on labor market outcomes. Notes: Employment includes the active phase of partial retirement. SSW is calculated with the planning age of 55 at the age of 59. SSW is multiplied by 1,000,000. We control for monthly age and cohort fixed effects, education, and changes in the legislation for disability pensions and in the entitlement rules for unemployment insurance and the economic sector. Standard errors in parentheses are clustered on the individual level. Significance levels: ${ }^{*} p<0.05,{ }^{* *} p<0.01$. The pre-reform mean is calculated for the pre-reform cohorts 1937 to 1939 . Source: SIAB7514, own calculations. 


\section{Appendix E:}

\begin{tabular}{|c|c|c|c|c|c|c|c|c|}
\hline & \multicolumn{2}{|c|}{ Inflow of older employees } & \multicolumn{2}{|c|}{ Dismissal protection } & \multicolumn{2}{|c|}{$\begin{array}{c}\text { Collective } \\
\text { bargaining agreement }\end{array}$} & \multicolumn{2}{|c|}{ R\&D expenditure } \\
\hline & Low & High & No & Yes & $\begin{array}{c}\text { Low } \\
\text { coverage }\end{array}$ & $\begin{array}{c}\text { High } \\
\text { coverage }\end{array}$ & Low & High \\
\hline No deductions & \multicolumn{2}{|c|}{ Reference } & \multicolumn{2}{|c|}{ Reference } & \multicolumn{2}{|c|}{ Reference } & \multicolumn{2}{|c|}{ Reference } \\
\hline $0.3-3.6$ & $\begin{array}{r}0.192 * * \\
(0.012)\end{array}$ & $\begin{array}{l}0.221^{* *} \\
(0.013)\end{array}$ & $\begin{array}{l}0.128 * * \\
(0.033)\end{array}$ & $\begin{array}{l}0.226^{* *} \\
(0.025)\end{array}$ & $\begin{array}{r}0.212^{* *} \\
(0.012)\end{array}$ & $\begin{array}{r}0.199 * * \\
(0.014)\end{array}$ & $\begin{array}{r}0.196^{* *} \\
(0.009)\end{array}$ & $\begin{array}{l}0.208^{* *} \\
(0.012)\end{array}$ \\
\hline $3.9-7.2$ & $\begin{array}{c}0.231^{* *} \\
(0.015)\end{array}$ & $\begin{array}{r}0.242^{* *} \\
(0.016)\end{array}$ & $\begin{array}{c}0.175^{* *} \\
(0.042)\end{array}$ & $\begin{array}{l}0.241^{* *} \\
(0.029)\end{array}$ & $\begin{array}{r}0.255^{* *} \\
(0.015)\end{array}$ & $\begin{array}{c}0.215^{* *} \\
(0.016)\end{array}$ & $\begin{array}{r}0.218^{* *} \\
(0.011)\end{array}$ & $\begin{array}{l}0.236^{* *} \\
(0.014)\end{array}$ \\
\hline $7.5-10.8$ & $\begin{array}{r}0.254^{* *} \\
(0.018)\end{array}$ & $\begin{array}{r}0.295^{* *} \\
(0.021)\end{array}$ & $\begin{array}{l}0.213^{* *} \\
(0.050)\end{array}$ & $\begin{array}{l}0.236^{* *} \\
(0.037)\end{array}$ & $\begin{array}{r}0.291^{* *} \\
(0.019)\end{array}$ & $\begin{array}{c}0.236^{* *} \\
(0.021)\end{array}$ & $\begin{array}{l}0.249 * * \\
(0.014)\end{array}$ & $\begin{array}{l}0.280^{* *} \\
(0.018)\end{array}$ \\
\hline $11.1-14.4$ & $\begin{array}{r}0.278^{* *} \\
(0.024)\end{array}$ & $\begin{array}{r}0.341^{* *} \\
(0.028)\end{array}$ & $\begin{array}{c}0.259 * * \\
(0.066)\end{array}$ & $\begin{array}{l}0.276^{* *} \\
(0.047)\end{array}$ & $\begin{array}{r}0.320^{* *} \\
(0.024)\end{array}$ & $\begin{array}{c}0.265^{* *} \\
(0.028)\end{array}$ & $\begin{array}{r}0.289 * * \\
(0.018)\end{array}$ & $\begin{array}{l}0.305^{* *} \\
(0.024)\end{array}$ \\
\hline $14.7-18.0$ & $\begin{array}{r}0.359 * * \\
(0.038)\end{array}$ & $\begin{array}{r}0.327^{* *} \\
(0.040) \\
\end{array}$ & $\begin{array}{l}0.276 * * \\
(0.099) \\
\end{array}$ & $\begin{array}{l}0.276^{* *} \\
(0.073) \\
\end{array}$ & $\begin{array}{r}0.357^{* *} \\
(0.036) \\
\end{array}$ & $\begin{array}{c}0.289 * * \\
(0.042) \\
\end{array}$ & $\begin{array}{l}0.303^{* *} \\
(0.027) \\
\end{array}$ & $\begin{array}{l}0.348^{* *} \\
(0.037)\end{array}$ \\
\hline $\mathrm{N}$ & 116,388 & 115,778 & 12,871 & 30,808 & 116,815 & 105,896 & 226,310 & 134,322 \\
\hline $\begin{array}{l}\text { Effect of a 1-year NRA increase } \\
\text { in months }\end{array}$ & $\begin{aligned} 2.390^{* *} \\
(0.549)\end{aligned}$ & $\begin{array}{l}2.750^{* *} \\
(0.529)\end{array}$ & $\begin{array}{c}1.658 \\
(1.081)\end{array}$ & $\begin{array}{l}3.125^{* *} \\
(0.635)\end{array}$ & $\begin{array}{l}1.739 * * \\
(0.554)\end{array}$ & $\begin{array}{c}2.262^{* *} \\
(0.564)\end{array}$ & $\begin{array}{c}2.397^{* *} \\
(0.391)\end{array}$ & $\begin{array}{l}2.200^{* *} \\
(0.509)\end{array}$ \\
\hline Pre-reform mean & 0.118 & 0.127 & 0.127 & 0.102 & 0.124 & 0.119 & 0.131 & 0.103 \\
\hline $\mathrm{R}^{2}$ & 0.323 & 0.317 & 0.594 & 0.428 & 0.325 & 0.341 & 0.301 & 0.315 \\
\hline
\end{tabular}

Tab. E1. Employment effects for women without bridge paths by employer groups. Notes: Employer groups are defined as in Tables 2 to 5 . We control for SSW with planning age of 55, and changes in the legislation for disability pensions and in the entitlement rules for unemployment insurance. Moreover, we consider the job exposure and education, regional unemployment rates, and firm characteristics in our estimation. Standard errors in parentheses are clustered on the individual level. The coefficients marked in bold mean that the firm types are at least significantly different at the 5\% level. The pre-reform mean is calculated for the cohorts 1937 to 1939 . Source: SIAB7514, own calculations. 